University of Chicago Law School

Chicago Unbound

Coase-Sandor Working Paper Series in Law and Economics

1999

\title{
Multiple Victim Public Shootings, Bombings, and Right-to-Carry Concealed Handgun Laws: Contrasting Private and Public Law Enforcement
}

John Lott

John.Lott@chicagounbound.edu

William M. Landes

William.Landes@chicagounbound.edu

Follow this and additional works at: https://chicagounbound.uchicago.edu/law_and_economics

Part of the Law Commons

\section{Recommended Citation}

John Lott \& William M. Landes, "Multiple Victim Public Shootings, Bombings, and Right-to-Carry Concealed Handgun Laws: Contrasting Private and Public Law Enforcement" (John M. Olin Program in Law and Economics Working Paper No. 73, 1999).

This Working Paper is brought to you for free and open access by the Coase-Sandor Institute for Law and Economics at Chicago Unbound. It has been accepted for inclusion in Coase-Sandor Working Paper Series in Law and Economics by an authorized administrator of Chicago Unbound. For more information, please contact unbound@law.uchicago.edu. 


\section{H IC AG O}

JOHN M. OLIN LAW \& ECONOMICS W ORKING PAPER N0.73 (2D SERIES)

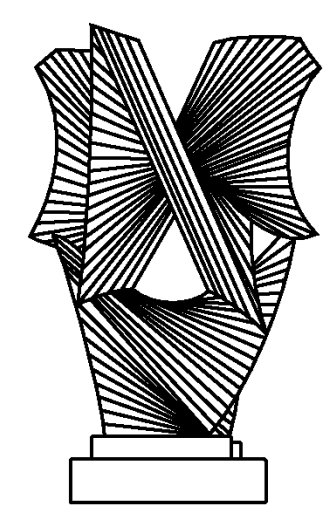

Mult ipl e Vict im Publ ic Shoot ings, Bombings, and Right-to-Carry Conceal ed H andgun Laws: Contrasting Private and Publ ic Law Enforcement John R. Lott, Jr. and William M . Landes

THE LAW SCHOOL

THE UNIVERSITY OF CHICAGO

This paper is available on-line at the $\mathrm{C}$ hicago W orking Paper Series index at: http://www.law.uchicago.edu/Publications/W orking/index.html

This paper is also available from the Social Science R esearch $N$ etwork at:

http://papers.ssrn.com/paper.taf?abstract_id=161637 


\title{
M ultiple Vict im Publ ic Shootings, Bombings, and Right-to-Carry Conceal ed H andgun Laws: Contrasting Private and Public Law Enforcement
}

\author{
John R. Lott, Jr. and William M. Landes ${ }^{1}$
}

\section{Int roduction}

Few events obtain the same instant national and even worldwide news coverage as when several people are shot and killed in a public place. The worst examples in the U nited States come readily to mind: Colin Ferguson killed 6 people during his rampage on the Long Island (NY) Railroad in December 1993; 22 people were killed during the 0 ctober 1991 shooting in L uby's C afeteria in Killeen, T exas; 5 persons died at the Cleveland Elementary School in Stockton, California in January 1989; and 21 persons were killed at the San Ysidro, C alifornia M CD onald's in July, 1984. Shootings by disgruntled post office employees, has led to the phrase "going postal" entering our language. And with the recent public school shootings, a sense of urgency has also been added to the discussion.

The most common suggestion for reducing the incidence of public shootings (the term we use to denote shootings in public places where two or more individuals are killed or injured) calls for greater regulation of guns. For example, recent public shootings in Tasmania, A ustralia and D unblane, Scotland have lead to strict gun

\footnotetext{
1 Lott is John M. O lin Fellow in Law and Economics and Landes is Clifton $R$. M usser Professor of $L$ aw \& E conomics at the University of $C$ hicago $L$ aw School. We would like to thank Edward Glaeser, M itch Polinsky and participants in seminars at the A rizona State University, Auburn University, University of Chicago, Claremont G raduate School, University of $\mathrm{H}$ ouston, University of Illinois, U niversity of $\mathrm{K}$ ansas, University of M iami, $\mathrm{N}$ ew $\mathrm{Y}$ ork University, University of O klahoma, Rice University, U niversity of Texas at A ustin, University of T exas at Dallas, W illiam and M ary University, and Yeshiva University School of $L$ aw as well as participants at the Economics of $\mathrm{L}$ aw Enforcement Conference at $\mathrm{H}$ arvard $\mathrm{L}$ aw School, A ssociation of A merican $L$ aw Schools $M$ eetings, A merican $E$ conomic A ssociation M eetings, $M$ idwestern E conomic A ssociation M eetings, Southern E conomic A ssociation $M$ eetings, and W estern Economic A ssociation M eetings.
} 
prohibitions in those countries. And after a 1997 shooting at the top of the E mpire State Building in which one person was killed, the $\mathrm{M}$ ayor of $\mathrm{N}$ ew $\mathrm{Y}$ ork called for national gun licensing laws. O ther laws restricting access to guns, such as waiting periods, are often justified as producing a cooling off period to prevent shooting sprees. $Y$ et, the response to these shootings has not been uniform. In T exas and other states, multiple shooting incidents may have helped pave the way for passage of concealed handgun laws permitting lawabiding citizens to carry handguns. T errorist shootings in I srael have lead to wider licensing of citizens to carry concealed handguns. (I n this paper, we use the term "shall issue law" or "right-to-carry" to denote a state law that sets up objective criteria for a law-abiding citizen to obtain a permit to carry a concealed handgun.)

$\mathrm{N}$ ot surprisingly, those opposed to concealed handgun laws point to the loss of life and injuries that result from these shootings. Their argument is straightforward: "If you introduce a gun into a violent encounter, it increases the chance that someone will die."2 Since a large number of murders may arise from fits of rage that are quickly regretted, keeping guns out of people's reach (even temporarily) might prevent deaths in many instances. ${ }^{3}$ Shootings in public places may be the most visible manifestation of individuals who might have refrained from such acts but for having access to guns. For example, in the recent rash of school shootings in 1997 and 1998, the perpetrators obtained their guns from relatives or neighbors. $\mathrm{H}$ ad no guns been accessible, the acts may not have been committed.

2 Philip Cook quoted in Editorial, Cincinnati Enquirer, Jan. 23, 1996, A 8. Others share this belief. "It's common sense," says Doug W eil, research director at the $\mathrm{C}$ enter to Prevent $\mathrm{H}$ andgun Violence, in W ashington. "T he more guns people are carrying, the more likely it is that ordinary confrontations will escalate into violent confrontations" (W illiam Tucker, "M aybe Y ou Should C arry A H andgun," The Weekly Standard, D ec. 16, 1996, p. 30).

3 See P. J. Cook, "The Role of Firearms in Violent Crime," in M.E. Wolfgang and N.A. Werner, eds., Criminal Violence, Sage Publishers: Newbury, N.J.(1982) and Franklin Zimring, "The M edium is the M essage: Firearm Caliber as a D eterminant of Death from A ssault," Journal Legal Studies, 1 (1972) for these arguments. 
In contrast, proponents of concealed handgun laws point to the potential use of guns for defensive purposes. They argue that the prospect of encountering a victim who is armed may deter a criminal from an attack in the first place. $\mathrm{N}$ ational polls indicate that people use guns defensively against criminal attacks somewhere between 760,000 and 3.5 million times per year. ${ }^{4} \mathrm{D}$ ata from the $\mathrm{D}$ epartment of Justice's N ational C rime Victimization Survey from 1979 to 1987 indicate that the risk of serious injury from a criminal attack is 2.5 times greater for women offering no resistance than for women resisting with a gun (Southwick, 1996). ${ }^{5}$ The most comprehensive study of laws permitting individuals to carry concealed weapons indicates that these laws reduce murder rates by about 10 percent, with similar declines in other violent crimes ( $L$ ott 1998b but see related comments by Bartley et. al., 1998; Black and Nagin, 1998; Bronars and L ott, 1998; Plassman and Tideman, 1998; L ott and M ustard, 1997; and Lott, 1998a). And contrary to a popular misconception, the use of concealed handguns by permit holders are virtually never involved in the commission of crime, let alone murder (L ott, 1998b).6

Just as advocates of greater regulation of guns point to shooting sprees that kill or maim many individuals as evidence supporting their position, opponents point to anecdotal evidence supporting more permissive handgun laws. During the Luby's Cafeteria shooting one of the restaurant's patrons, an expert marksman, had left her handgun in her car to comply with the Texas state law existing at the time. In an incident in 1997, a gunman in a Florida restaurant was prevented from shooting people by the quick

\footnotetext{
${ }^{4} \mathrm{~K}$ leck, $\mathrm{G}$ ary, and $\mathrm{M}$ arc $\mathrm{G}$ ertz, "A rmed Resistance to $\mathrm{C}$ rime: The Prevalence and $N$ ature of Self-Defense with a Gun," 86 Journal of Criminal Law and Criminology 86 (Fall 1995).

5 There are problems with the $\mathrm{N}$ ational $\mathrm{C}$ rime Victimization Survey both in terms of its nonrepresentative sample (for example, it weights too heavily urban and minority populations) and its failure to adjust for many people not admitting to a law enforcement agency that they used a gun, even defensively. Unfortunately, this survey provides the only available evidence how the probability of significant injury varies with level and type of resistance.

6 W e add that no data are available on whether handguns lawfully bought by permit holders are used in crimes by another party at a later date.
} 
reactions of two people with concealed handguns. ${ }^{7}$ (See L ott (1998b) for a more complete list of such cases.) Internationally, similar examples can be found. On M arch 13, 1997, a Jordanian soldier shot seven young I sraeli girls to death while they were visiting Jordan's so-called "I sland of Peace." A ccording to newspaper reports, the Israelis had "complied with Jordanian requests to leave their weapons behind when they entered the border enclave. 0 therwise, they might have been able to stop the shooting, several parents said."8

R eferring to the July 1984 massacre at a San Y sidro, California, $M$ CD onald's restaurant, I sraeli criminologist A braham T ennenbaum wrote that:

what occurred at a [crowded venue in] Jerusalem some weeks before the California $M$ CD onald's massacre: three terrorists who attempted to machine-gun the throng managed to kill only one victim before being shot down by handgun carrying I sraelis. Presented to the press the next day, the surviving terrorist complained that his group had not realized that Israeli civilians were armed. The terrorists had planned to machine-gun a succession of crowd spots, thinking that they would be able to escape before the police or army could arrive to deal with them. ${ }^{9}$

O bviously allowing I sraeli citizens to carry concealed handguns has not eliminated terrorist attacks. Indeed, terrorists may well have responded to the difficulty of successfully shooting civilians in public places by substituting bombings, which allow potential victims little chance to respond.

A necdotal evidence cannot resolve the question whether allowing persons to carry concealed handguns will save or cost lives. In this study, we provide a systematic empirical analysis of the effects of different gun laws on multiple victim public shootings. W e focus

7 Allison Thompson, R obber G ets Outgunned on W estside," Florida TimesU nion ( Jacksonville, FL ),September 24, 1997, p. B 1.

8 Rebecca Trounson, "A nxiety, A nger Surround Return of Young Survivors," L os Angeles Times, M arch 14, 1997, p. A 1

${ }^{9}$ Baltimore Sun, O ct. 26, 1991. As referenced in an article by D on Kates and Dan Polsby. "Of G enocide and Disarmament," Journal of Criminal Law and Criminology, 86 (Fall 1995): 252. 
primarily on nondiscretionary (or "shall issue") concealed handgun laws although we also look at evidence on the role of waiting periods and additional penalties imposed on individuals who use guns in the commission of a crime.

W e analyze multiple victim public shootings (hereafter, multiple shootings or killings) in the United States in the period 1977 to 1995.10 The main advantage of restricting our study to U.S. data is that we can compare states with and without shall issue laws at different points in time (other things constant) and, therefore, can estimate the effects of a change in the law within a state during the sample period. In contrast, time series data for a single country faces the problem that many different events may occur at around the same time which makes it difficult to disentangle the impact of a change in the law from other factors. And an international study across different countries faces problems in finding comparable data on gun laws, crime rates, and gun ownership. O ur study ends in 1995 because many of the variables we use are not available after than date.

A few words about why we study multiple shootings. A side from the public attention these acts receive, multiple shootings allow us to test the applicability of economics to an area believed to be far outside the domain of economics. Perpetrators of these acts are often thought to be psychotic or irrational and hence not responsive to costs and benefits. Thus, legal sanctions or, as in this case, the prospect of encountering an armed individual during a shooting spree would have no deterrent effect on these individuals. Indeed, the act itself is cited as powerful evidence of irrational or psychotic behavior since a sane person would never kill helpless victims in a

10 W hile the recent rash of public school shootings during the 1997-98 school took place after the period of our study, these incidents raise questions about the unintentional consequences of laws. The five public school shootings took place after a 1995 federal law banned guns (including permitted concealed handguns) within a thousand feet of a school. The possibility exists that attempts to outlaw guns from schools, no matter how well meaning, may have produced perverse effects. It is interesting to note that during the 1977 to 1995 period, 15 shootings took place in schools in states without right-to-carry laws and only one took place in a state with this type of law. There were 19 deaths and 97 injuries in states without the law, while there was one death and two injuries in states with the law. 
public place. The claim is then made that a law permitting individuals to carry concealed weapons couldn't possibly deter shooting sprees in public places (though it might reduce the number of people killed or wounded). And since these laws might well increase the availability of guns to potential perpetrators, the combination of criminal irrationality and greater availability of guns might lead to an increase in the number of incidents of multiple shootings.

In contrast, the economic model of crime predicts that a shall issue law will raise the potential perpetrator's cost of acting (e.g., he might be wounded or killed if he acts) and lower his expected benefit (e.g., he will do less damage if he encounters armed resistance). Although not all offenders will alter their behavior in response to a shall issue law, some individuals will be deterred from carrying out a shooting spree because the resulting changes in costs and benefits will be sufficiently large to make their net gain from acting negative. $\mathrm{H}$ ow large the deterrent effect is depends on how many potential offenders are close enough to the margin so that the passage of a shall issue law changes the net benefit from positive to negative. E conomics predicts, therefore, that shall issue laws will reduce the number of mass shootings (subject to the "greater availability of guns" qualification noted above) though the magnitude of this response is uncertain.

A study of multiple shootings also allows us to compare whether a shall issue law will produce a bigger deterrent effect on multiple shootings than on ordinary murders and other crimes. This may appear surprising in light of the claimed irrationality of individuals who go on shooting sprees. But another consideration points in the opposite direction. Suppose a shall issue law deters crime primarily by raising the probability that a perpetrator will encounter a potential victim who is armed. In a single victim crime, this probability is likely to be very low. $\mathrm{H}$ ence the deterrent effect of the law-though negative- might be relatively small. N ow consider a shooting spree in a public place. The likelihood that one or more potential victims or bystanders are armed would be very large even though the probability that any particular individual is armed is very 
low. ${ }^{11}$ In principle, this suggests a testable hypothesis: a shall issue law will have a bigger deterrent effect on shooting sprees in public places than on more conventional crimes. Finally, because the presence of citizens with concealed handguns may be able to stop attacks before the police are able to arrive, our data also allows us to provide the first evidence that we know of concerning whether the severity of those crimes that still take place can be mitigated.

\section{Multipl e Vict im Publ ic Shoot ings: A First Look}

W e define a multiple shooting as one in which two or more people are killed or wounded in a public place. "Public place" refers to a shooting that occurred in a church, business, bar, street, government building, public transit, place of employment, park, health care facility, mall or restaurant. W e collected data on these shootings from articles reporting multiple shootings during the 1977 to 1995 period in the Lexis/N exis computerized database. O ur sample does not include all multiple shootings in the database. W e exclude the following: those that were the byproduct of another crime (e.g., a robbery or drug deal); shootings that involved gang activity (e.g., drive by shootings); professional hits or shootings related to organized crime; and serial killings or killings that took place over the span of more than one day. ${ }^{12} \mathrm{~A}$ lthough there is no bright line between different types of multiple shootings, there are several reasons for limiting our sample as we do.

1. O ne of us has already studied the effects of shall issue laws on murder rates in general. $\mathrm{H}$ ence by adding shootings from robberies,

11 To illustrate, let the probability ( $p$ ) that a single individual is carrying a concealed handgun equal .10. A ssume further that there are 10 individuals in a public place. Then the probability that at least one of them is armed is about .65 $\left(=1-(.9)^{10}\right)$.

12 In a recent paper (see $T$. Petee, $K$. Padgett and $T$. Y ork, D ebunking the Stereotype: An Examination of $M$ ass $M$ urder in Public Places, $1 \mathrm{H}$ omicide Studies 317 (1997)) the authors find felony related mass murders account for 36 percent and gang motivated 5.8 percent of mass murder incidents over the 1965 to 1995 period. That study defines mass murders as the killing three or more persons (so it has much fewer incidents than our sample). 
gang activity and so forth to our sample we risk duplicating earlier work.

2. Shall issue laws permit law-abiding citizens to carry guns so these laws should have little impact on killings related to gang activity, drug deals and organized crime. Individuals involved in these activities are already engaged in unlawful activities that often require them to carry guns. In short, these persons carry guns independent of whether the law permits them to do so. H ence a "shall issue" should have little effect on their behavior.

3. Restricting our study to shootings in public places allows us to concentrate on places where economic theory suggests that shall issue laws will have their greatest effect. ${ }^{13} \mathrm{~W}$ e expect this because more citizens will be carrying concealed handguns in public places after a law allowing them to carry a gun has been passed. A nd a shall issue law should also be a more effective deterrent if the potential perpetrator either knows or is uncertain whether the intended victim is armed. Conversely the law should have no effect if the offender knows in advance that the victim is not armed. But such knowledge is unlikely for public places. So unless there are explicit restrictions on carrying guns in certain places (e.g., near schools), a shall issue law should increase the likelihood that a potential victim or bystander is armed. ${ }^{14}$

4. O ne can also question our definition of multiple shootings as requiring two or more killings or injuries. $L$ ater in the paper we look

13 A Ischuler (1997, p. 369) claims that concealed handguns should only deter crimes involving strangers. 0 ur response is that concealed handguns can deter crimes involving acquaintances as well as strangers, though deterrence involving acquaintances might be more easily thought of as similar to open carrying of guns. The big effect of concealed handguns is that they may allow people to be able to now defend themselves outside of their home or business. The passage of the concealed handgun laws may deter crimes against acquaintances simply to the extent to which it increases gun ownership.

$14 \mathrm{M}$ ost states allow private businesses to decide whether permit holders are allowed to carry concealed handguns on their premises. State rules may also vary with regard to other places such as government buildings, churches, and bars. 
at alternative definitions requiring greater number of deaths and injuries.

Tables 1 and 2 present data on multiple shootings for the United States as a whole, and for states with and without shall issue laws. W e find that states without shall issue laws had more deaths and injuries from multiple shootings per year (both in absolute numbers and on a per capita basis) during the 1977 to 1995 period. $\mathrm{N}$ ote also that the number of states without shall issue laws declined from 43 to 29 and the percentage of the U.S. population in these states fell from 91.5 to 68 percent in this period. Yet states without shall issue laws still account for the overwhelming majority (often over 90 percent) of deaths and injuries. The different rates of shootings, murders, or injuries are very consistent over time and do not arise from a few unusual years.

T ables 3 and 4 look more closely at the 14 states that adopted shall issue laws between 1977 and 1995.15 (No state has ever repealed this law.) Table 3 shows a sharp drop in multiple murders and injuries per 100,000 persons after the passage of a shall issue law. M urders fell by 89 percent and injuries by 82 percent. Table 4 indicates that this drop occurred largely during the first full year after a state enacted its law (year " 1 " in the first column). O verall, the decline is so large that we observe zero multiple killings in three of the eight years after the passage of a law, an event that did not occur

15 The fourteen states that enacted "shall issue" or "right-to-carry" laws in the 1977 to 1995 period (dates in parentheses) are as follows: Alaska (1994), A rizona (1994), Florida (1987), G eorgia (1989), I daho (1990), M aine (1985), M ississippi (1990), M ontana (1991), O regon (1990), Pennsylvania (1989), Tennessee (1994), Virginia (1988), W est Virginia (1989), and W yoming (1994). The following eight states had "shall issue" laws over the entire period: A labama, Connecticut, Indiana, N ew $\mathrm{H}$ ampshire, North Dakota, South D akota, Vermont and W ashington. Data on states having laws prior to 1993 are from Clayton E. C ramer and D avid B. Kopel, Shall I ssue: The N ew W ave of Concealed $\mathrm{H}$ andgun Permit Laws, 62 T ennessee Law Review, 679 (1995). W e used a $\mathrm{N}$ exis search to determine the state and date for states passing laws between 1993 and 1995. These two sources were also used in L ott and M ustard (1997). B ecause of objections raised to the dates for "shall issue" laws in M aine and Virginia (see the discussion in Lott and M ustard), the regression analysis presented in part III examines the sensitivity of our findings to alternative dates for $\mathrm{M}$ aine and Virginia. 
during any year before passage of the law. ${ }^{16}$ T able 3 also presents data on a narrower sample consisting of multiple shootings that appeared in the first section of the $\mathrm{N}$ ew York Times at the time the shootings took place. We use this sample as an estimate of more serious or, at least, more notorious multiple shootings. Similar to the data on all multiple shootings, the $\mathrm{N}$ ew York Times data show a decline of 91 percent in the rate of multiple shootings after a state adopted a shall issue law. Finally, we consider the possibility that shall issue laws lead criminals to substitute bombings for shootings. Data on bombings (from the Bureau of Alcohol, Tobacco and Firearms annual publication Arson and Explosives: Incidents Report) suggest no systematic impact on the number of bombings. A fter the passage of shall issue laws, actual and attempted bombings increased slightly, incendiary bombings fell and other bomb-related incidents (involving stolen explosives, threats to treasury facilities, and hoax devices) declined compared to the before law period.

\section{Account ing for 0 ther Factors}

A lthough the above tables suggest that shall issue laws reduce mass shootings, other factors may explain these changes. To take account of this possibility, we estimated regression equations with the following state specific variables: the arrest rate for murder; real per capita personal income; real per capita government payments for income maintenance, unemployment insurance and retirement; the unemployment rate; the poverty rate; state population and population squared; and a set of demographic variables that subdivide a state's population into 36 different race, sex, and age groups. W e also include year and state specific dummy variables in the regression analysis. T able 5 lists the variables included in the regression analysis. Thus our results hold constant both the effects of any national trends and state-specific effects on multiple shootings which may coincide with the adoption of shall issue laws. So, for example, if the multiple shooting rate declines nationally between two years, the regression coefficient on the law variable tests for whether the decline is relatively greater in states that adopted shall issue laws

16 of course, there were zero mass shootings in individual states in particular years before the passage of concealed handgun laws. 
during the two year period. This approach may actually understate the impact of shall issue laws since the year dummy variables may also pick up some of the changes attributed to the increasing number of states that passed these laws.

Table 6 presents regressions for twelve different dependent variables (six for multiple shootings and six for bombings) using the simplest specifications of the shall issue law variable-a dummy law variable which equals one if a state has a concealed handgun or "shall issue' law and zero otherwise. The regression analysis contains 953 observations (50 states and the District of Columbia for 19 years minus 16 observations for various states and years in which we lacked data on the arrest rate). ${ }^{17} \mathrm{~T}$ o simplify the table, we only present the regression coefficients (and t-statistics) on the dummy law variable.

The results of T able 6 indicate that concealed handguns laws significantly reduce multiple shootings in public places (but have no systematic effects on bombings). F or example, shall issue laws appear to lower the combined number of killings and injuries (equation (3)) in a state by 11.1 per 10 million people per year, or by more than 80 percent of a one standard deviation change in the murder and injury rate from multiple shootings. Equations (4) and (5) imply that the average state passing these laws reduces the number of murders and injuries by 6.9 and 6.5 persons respectively. Indeed these estimated effects are so large that they often exceed the annual average number of murders and injuries from public shootings in a state (either absolutely or per 100,000 persons). To be sure, we expect large deterrent effects from these laws because of the high probability that one or more potential victim or bystander will be harmed. Still the drop in murders and injuries is surprisingly large. A nd as we shall see, alternative measures of shootings and adding other control variables do not seem to reduce the magnitude of the law's effect.

T urning to the other variables in the regressions in T able 6, we find that states with larger populations have more multiple shooting

17 The states and years of the missing observations are as follows: Florida (1988); Illinois (1993-95); I owa (1991); Kansas (1993-95); K entucky (1988); M ontana (1994-95); N ew H ampshire (1984 and 1995); Pennsylvania (1995) and Vermont (1978-79). As a further check on our results, we reestimated the regressions in Tables 6 and 7 deleting the arrest variable and adding the 16 missing observations. The coefficients and levels of significance on the shall issue law variable were virtually unchanged. 
deaths and injuries per 100,000 persons though the rate increases at a decreasing rate. We also find that personal income, poverty and population density are insignificant while retirement payments and unemployment have positive and significant (or marginally significant) effects on the murder rate. Higher arrest rates for murder are associated with fewer multiple murders and killings but these results are never statistically significant ${ }^{18}$ (T he full regressions are available from the authors on request.)

Finally, notice that the number of bombings in T able 6 (with the exception of "other bombing incidents" in eq. 12) are not related to shall issue laws. Some types of bombings appear to rise and others fall after the passage of a law, the signs often depend on whether bombings are expressed as a rate or an absolute number, and five of the six coefficients are not statistically significant. In short, there does not appear any significant substitution between shootings and bombings in states enacting "shall issue" laws. (In the remaining tables we do not report the results for the bombing regressions because, in almost all cases, bombings are not significantly related to shall issue laws.)

Table 7 replaces the simple dummy law variable with two time trend law variables for those states that passed laws between 1985 (the first year a state passed a law during the 1977 to 1995 sample period) and 1995. The first is a time trend variable before passage of the law that takes the value 0 in the year the law is passed (and all years following passage), -1 in the year before passage, -2 in the second year before passage and so forth. The second is a post law variable that takes the value 0 in the year the law is passed (and 0 in all years before passage), 1 in the first year after passage and so on. The main reason for this specification is that we expect the impact of shall issue laws to increase over time as more people obtain permits. It may take many years after enacting a handgun law for states to reach their long run level of permits. For states in which

18 W e note that the arrest rate variable understates the actual (or expected) arrest rate of individuals who go on shooting sprees. M ore than 90 percent of these offenders are either arrested or killed, which is slightly greater than the overall arrest rate for murder. The 90 percent figure (which comes from a $\mathrm{N}$ exis search) represents perpetrators who were immediately captured or killed. W e do not know whether those who escaped were apprehended later. 
data on permits are available the share of the population with permits is still increasing a decade after the passage of the law ( $\mathrm{L}$ ott, 1998b, p. 75). ${ }^{19}$

In Table 7, we find that deaths or injuries from mass shootings are rising before the passage of the law and falling afterwards (though the before law trend is only marginally significant in most cases). The F-test for the differences in these time trends is always significant at least at the .02 level. A s expected, therefore, the more years a shall issue law has been in effect in the 14 states that passed laws starting in 1985, the greater the decline in murders and injuries (both absolutely and per 100,000) from mass public shootings.

Because of the relatively large number of shootings that occurred in the year prior to enactment of the laws and the possibility that our results might be picking up a simple regression to the mean, we reestimated the regressions in Tables 6 and 7 after removing the observations for that year. All of the shall issue coefficients in the shooting regressions remained statistically significant, with the single exception of the injury rate in Table 6 which was negative but no longer statistically significant.20

19 W e note three other points related to T able 7.

(1) Eight states in our sample had shall issue laws during the entire period. All eight passed their laws before 1960 and so should have reached their equilibrium level of permits before 1977 (the first year in our sample). These value assigned to two time trend variables for these states and states that never enacted laws is zero.

(2) A second reason for the split time trend specification is that if (relative to other states) shootings in states that pass shall issue laws are rising before the law goes into effect and falling thereafter, a dummy law variable would underestimate the law's impact (even though the regression contains year dummy variables). For example, imagine that the increase in shootings before the law is symmetrical with the decline after the law. A simple dummy variable for the presence or absence of the law would indicate that the law had no effect yet the law might well have caused a change in the trend from positive to negative.

(3) We also estimated regressions adding two time-squared variables for the law variables. H ere we find the same pattern of declining murders and injuries after passage of the law with the decline flattening out by the sixth year after enactment of the law.

20 Because of the relatively large number of shootings that occurred in the year prior to enactment of the laws and the possibility that our results might be picking up a simple regression to the mean, we reestimated the regressions in 
T able 8 adds other law variables that may influence the number of mass shootings. The law variables include the following: a dummy variable if a state has a waiting period before an individual can obtain a gun and the length of this period in days and dayssquared (see L ott and M ustard for a discussion of this variable); the probability of execution (equal to the number of executions per murder in a given year); and a dummy variable for whether a state imposes additional penalties for using a gun in the commission of a crime.21

Three conclusions emerge from T able 8. First, the statistically significant negative impact of shall issue laws on mass public shootings continues to hold. Second, the regression coefficients on the shall issues variables are of the same magnitude as in Table 7 . Third, the other gun related law variables and the capital punishment variable have no significant impact on mass shootings. The point estimates on the waiting period variables sometimes imply that longer waiting periods increase the risk of mass public shootings and other times they imply the reverse. In no case is the waiting period variable statistically significant. Although the execution rate has a negative coefficient in the six regressions, it is never statistically significant. The execution variable itself may be only weakly related to the probability that a mass murderer will be executed given the

Tables 6 and 7 after removing the observations for that year. All of the shall issue coefficients in the shooting regressions remained statistically significant, with the single exception of the injury rate in Table 6 which was negative but no longer statistically significant. For example, the t-statistics for the shall issue dummies in specifications 1 to 3 in T able 6 are -3.02, -1.456, and -2.295; and the F-statistics for the before and after trends corresponding to specifications 1 to 3 in T able 7 are 20.15, 6.67, and 13.99. Similar results were also obtained when the two years preceding a state's adoption of the law were deleted from the sample. The t-statistics for the shall issue dummies in specifications 1 to 3 in Table 6 are $-2.732,-1.50$, and -2.281 ; and the Fstatistics for the before and after trends corresponding to specifications 1 to 3 in Table 7 are 20.96, 7.92, and 15.29.

21 See the Tracy L. Snell, Prisoners executed under civil authority in the United States, by year, region, and jurisdiction, 1977-1995, Bureau of Justice Statistics, M ay 14, 1997. For the source of penalties imposed for when a gun is used in a commission of a crime see Thomas B. M arvell and Carl E. M oody, The Impact of E nhanced Priosn Terms for Felonies Committed with $G$ uns," Criminology 33 (M ay 1995): 247, 258-61. 
long delays before execution and its over-inclusiveness (i.e., the variable measures the execution rate for all murders not mass murders), so we also tried including a simple dummy variable for whether the dead penalty was in effect. H owever, the coefficient was never statistically significant and did not alter our other results. Finally, the law variable denoting the imposition of additional penalties for using a gun in a crime is insignificant.

The impact of the death penalty on public shootings stands in sharp contrast to evidence that we have put together on murder rates using county level data from 1977 to 1995 . W e find that a one percentage point increase in the execution rate is associated with a seven percent decline in the overall murder rate and the effect is statistically significant at better than .01 percent level. The question is why does the presence of concealed handgun laws deter multiple victim shootings when other penalties fail to have an effect. 0 ne possibility is that the execution rate does not deter mass public killers because they already die at such high rates from their crime, but concealed handgun laws deter attacks because the killers are committing the crime to kill or injure a large number of people and that their return from these attacks is reduced when citizens with concealed handguns can limit the carnage.

We also reestimated the regressions by including both the murder and total bombing rates as explanatory variables because there may be some overlap between factors that explain public shootings, overall murders and bombings that are not taken into account by the independent variables in the previous regressions. Adding these variables to the regressions in Tables 6,7 and 8 produces little change from our previous results. In 17 of the 18 regressions, the shall issue variable has a negative and statistically significant effect on multiple shootings. 22

\section{Alter native M easures of Multipl e Shootings}

22 Even in the one case where the coefficient is no longer statistically significant it is still negative. The t-statistic is -1.63 in the regression on injuries per 100,000 persons using the specification in Table 6 with the addition of the murder and bombing variables. The murder rate is always positively related to mass shootings but statistically significant in only six of the 18 regression equations. T otal bombings are never statistically significant in any of these regressions. 
The dependent variable in Table 9 is the number of multiple shootings reported in the first section of the $\mathrm{N}$ ew York Times. Because the Tobit regressions with state specific effects did not converge, we substituted regional dummy variables in the Tobit regressions. W e also present OLS estimates that include state fixed effects variables. Regional and even state fixed effects may be important if the $\mathrm{N}$ ew York Times has a regional or state bias in its coverage of shooting events. O verall, the results are consistent with our earlier findings. Both the dummy shall issue law variable and the split time trend variables indicate significant reductions in multiple shootings after the passage of the law. The OLS estimates also produce negative effects of the law but these estimates are less significant (i.e., they are generally significant at the .10 but not .05 level).

The only other study that we know of on multiple victim murders defines the offense more narrowly than we have, and it limits the definition to four or more people killed in the shooting (Petee et. al., 1997). This definition sharply lowers the number of public shootings to 36 incidents during the 1977 - 1995 period. W e attempted to explain both the per capita and absolute number of people killed in these shootings using the same specifications as in Tables 6 and 7.23 The results are similar to those reported earlier. W e find that shall issue laws reduce the number of deaths, and that these deaths were increasing before passage of the law and falling thereafter. ${ }^{24}$.

\footnotetext{
${ }^{23}$ A gain, the Tobit estimates do not converge when state fixed effects are used for there is not enough variation in the data to distinguish the law's impact on these shootings with state fixed effects. Consequently, the state fixed effects are replaced with regional dummies ( $N$ ortheast, $M$ idwest, South, and W est (the left out region)).

24 In explaining the per capita number of people killed, the shall issue concealed handgun dummy variable was -.1207502 (t-statistic $=1.966)$ and the difference in the before and after trends equaled -.057 ( $\mathrm{f}$ - statistic $=6.96$ ). $\mathrm{F}$ or the regressions explaining the number of people killed in a state, the shall issue concealed handgun dummy variable was -15.4 (t-statistic $=2.363$ ) and the difference in the before and after trends equaled -7.05 ( $\mathrm{f}$-statistic $=9.41$ ). The mean number of deaths per 100,000 persons per state per year is .0037 (standard deviation $=.0294$ ) and the mean number of deaths per state per year is .249 (standard deviation $=1.52$ ).
} 
$V$. The Number of Shoot ings and the N umber of People Killed or Injured Per Shooting

The presence of concealed handguns should reduce both the number of public shootings and the amount of harm caused by any one event. Consider the following examples. During a recent shooting spree at a public school in Pearl, M ississippi, an assistant principal retrieved his gun and physically immobilized the shooter before he caused additional harm (C N N , 0 ctober 2, 1997, 2:40 PM EST). And in the public school related shooting in Edinboro, Pennsylvania, which left one teacher dead, a shot gun pointed at offender while he was reloading his gun prevented additional harm (Reuters N ewswire, A pril 26, 1998). The police did not arrive for another ten minutes. The examples mentioned in the introduction also illustrate cases where shooters have been shot by citizens and thus presumably prevented from harming even more people. A lthough one can also imagine circumstances where shall issue laws increase the availability of guns to potential offenders or where guns used in self defense lead to more not less killings, our results so far strongly indicate that these effects, if they exist, are not sufficient to offset the overall negative impact of shall issue laws on multiple shootings.

$\mathrm{H}$ ere we separate the effects these laws have on the number of shootings from the number of people harmed. Suppose, for example, perpetrators are undeterred by legal penalties or the prospect of encountering an armed defender. Then the number of persons harmed per shootings could still fall (as the two school shooting examples suggest) if concealed handguns interfered with the offender's ability to carry out his plans. U sing either the dummy law variable or the before-and-after time trends, the coefficients in T able 10 indicate that concealed handguns reduce both the number of shootings and the number of people harmed.25 The evidence on whether shall issue laws have a bigger impact on the number of

$25 \mathrm{~N}$ ote that there are 234 observations in the deaths or injuries per shooting regressions although Table 1 indicates that there were 396 shootings in the sample period. The dependent variable in equations (1) - (3) in Table 10 equals the average number of deaths or injuries per shooting in a state in a year. $\mathrm{H}$ ence if there were two or more multiple shootings in a state in a year, this counted as one observation in the regression. 
people harmed relative to the number of shootings is mixed. The absolute size of the coefficient in the regression on deaths and injuries (equation (3)) is three times greater than in the shooting regression (equation (4)) but the elasticity is greater in latter than in the former regression (the means are 4.52 and .41 for the number of persons harmed and the number of shootings respectively). ${ }^{26}$

\section{Do Shoot ings Produce M ore Shoot ings?}

D oes a public shooting lead others to imitate or mimic the behavior of the first gunman? O ne might reason that the attention and notoriety surrounding a shooting by $A$ might encourage $B$ to undertake a similar act, and B's act might encourage $C$ and so on. The notion of crime "fad" or epidemic is not new. L andes (1978, pp. 16-18) investigated and rejected the hypothesis that the increase and subsequent decrease in airline hijackings in E urope and the United States over the 1961 to 1976 period could be explained by a fad rather than by the increase in apprehension rates and penalties.

To test for fads or imitative behavior, we calculate the number of mass shootings per month for the 228 months in the 1977 to 1995 period. W e specified the dependent variable in two ways: the number of monthly shootings and the difference in the number between adjacent months. The regression includes dependent variables denoting various monthly lags in either the number of shootings (or number reported in the $\mathrm{New}$ York Times) or the change in the number of shootings. W e control for the increase in the number of states with shall issue laws during this period by adding a variable denoting the percentage of the U.S. population covered by these laws. W e also include month dummy variables and a time trend (in months). Table 11 reports both Tobit and OLS estimates of the regression equations.

In T able 11, only the percent of the U.S. population covered by shall issue laws and the time trend variables are consistently significant in all eight regressions. The positive coefficients on the

26 W hile individuals with permits produce a large social benefit, they risk being shot by the attacker. We have no instances where people with permits have indeed been shot, but this risk surely raises the prospects of whether citizens with permits should be compensated or at least not have to pay large fees for obtaining a permit. 
lagged values of shootings in the first four regressions provide some weak evidence of faddish behavior. But the lagged values of the change in shootings in last four equations imply the opposite-i.e., the larger the increase in shootings during the prior months, the greater the decline in the current month. In short, the evidence on fads is mixed. 27

O ne reason we may not find significant evidence of faddish behavior is that lagged shootings and lagged stories on shootings in the $\mathrm{N}$ ew York T imes are highly collinear. To test this we reestimated the regressions in T able 11 using either lagged shootings or lagged stories by themselves. W e still find no systematic evidence of faddish behavior. Lagged values of shootings are positively related to monthly shootings while lagged differences are negatively related to differences in monthly shootings. A gain the percent of the population covered by shall issue laws continues to have negative and statistically significant effects on the number and change in the number of monthly shootings.

W hile the evidence provides little support for the copycat hypothesis, we note that our data contains shootings by adults. The recent public school shootings involving children might be different and more consistent with the imitative hypothesis. H owever, data on school shootings involve such a small sample that it is not possible to study these shootings separately.

\section{Explaining the Passage of Shall Issue Laws}

The previous specifications assume that the passage of a shall issue law is an exogenous event. Following Lott and M ustard (1997, pp. 39-48), we assume that the likelihood a state will enact a law depends on political influence variables that include the percentage of its population that are members of the $\mathrm{N}$ ational R ifle A ssociation, the percentage of votes received by the Republican presidential candidate in the state, lagged and changes in the rates of violent and property crime, and fixed regional effects. Since presidential elections occur every four years, we interacted the percentage voting

$27 \mathrm{~N}$ ote that $\mathrm{O}$ ctober appears to be the most dangerous month although he number of shootings in $\mathrm{O}$ ctober is only significantly greater than the number in January, September and November. Note, however, that the monthly dummy variables are not jointly significant. 
Republican with dummy variables for the years adjacent to the relevant elections. T hus, the percentage of the vote obtained in 1980 is multiplied by a year dummy for the years $1979-82$, and so on, through the 1996 election.

The first stage (see the bottom half of Table 12) implies that states adopting these laws are relatively Republican and have low violent crime but high property crime rates. Neither NRA membership nor rising violent and property crimes rates are statistically significant (though the NRA variable is marginally significant). The second stage regressions support our earlier results contained in T able 6. A dopting a shall issue law is associated with a significant decline in the combined number of multiple killings and injuries (both absolutely and per 100,000 persons). In the separate murder and injury regressions, the coefficients are always negative and either significant or marginally significant (a t-statistic greater that 1.65). .28

\section{Conclusion}

The results of this paper support the hypothesis that concealed handgun or shall issue laws reduce the number of multiple victim public shootings. A ttackers are deterred and the number of people injured or killed per attack is also reduced, thus for the first time providing evidence that the harm from crimes that still occur can be mitigated. The results are robust with respect to different specifications of the dependent variable, different specifications of the handgun law variable, and the inclusion of additional law variables (e.g., mandatory waiting periods and enhanced penalties for using a gun in the commission of a crime). $N$ ot only does the passage of a shall issue law have a significant impact on multiple shootings but it is the only law related variable that appears to have a significant impact. 0 ther law enforcement efforts from the arrest rate for murder to the death penalty to waiting periods and background checks are not systematically related to multiple

$28 \mathrm{As}$ a test of whether the shall issue laws were passed because of a shooting, we reestimated just first stage regression by itself after including the lagged murder or injury rate from the shootings to see if the law was adopted because of the shooting. W hile the coefficients on these lagged values were positive, neither variable was ever statistically significant. 
shootings. W e also find that shall issue laws deter both the number of multiple shootings and the amount of harm per shooting. Finally, because the presence of citizens with concealed handguns may be able to stop attacks before the police are able to arrive, our data also allows us to provide the first evidence on the reduction in severity of those crimes that still take place. 


\section{Bibliography}

A lschuler, A lbert W., "T wo G uns, Four G uns, Six G uns, M ore G uns: D oes A rming the Public Reduce C rime," Valparaiso L aw Review 31 (Spring 1997): 365-373.

Bartley, W illiam A lan; Cohen, M ark A. and Frobe, Luke. "T he Effect of Concealed W eapon Laws: Estimating M odel Uncertainty." E conomic Inquiry 36 (A pril 1998): 258-265.

Black, D an A. and D aniel S. Nagin, "Do 'Right-to-Carry' Laws D eter Violent Crime?" Journal of Legal Studies 27 (January 1998): 209-219.

Bronars, Stephen G. and John R. L ott, Jr., "C riminal D eterrence, Geographic Spillovers, and the Right to Carry Concealed $\mathrm{H}$ andguns," American E conomic R eview, 82 (M ay 1998): 475-478.

Cook, P. J., "T he Role of Firearms in Violent Crime," in M.E. Wolfgang and N.A. W erner, eds., Criminal Violence, Sage Publishers: N ewbury, N.J.(1982).

Kates, D on, and D an Polsby. "Of Genocide and Disarmament," Journal of Criminal L aw and Criminology, 86 (F all 1995): 247-256.

Kleck, Gary, and M arc Gertz, "A rmed Resistance to C rime: The Prevalence and $N$ ature of Self-D efense with a G un," 86 Lournal of Criminal L aw and Criminology 86 (Fall 1995): 150-187.

Landes, William M., "An Economic Study of U.S. Airline Hijacking, 1961-1976," Journal of Law and Economics 21 (A pril 1978): 1-32.

Lott, John R., Jr. and David M ustard, "C rime, D eterrence, and Right-to-C arry Concealed H andguns," Journal of L egal Studies 26 (January 1997): 1-68. 
Lott, John R., Jr., "The Concealed H andgun D ebate," Journal of L egal Studies 27 (January 1998a): 221-243.

L ott, John R ., Jr., M ore G uns, L ess Crime: U nderstanding Crime and Gun Control Laws, University of Chicago Press: Chicago, Illinois (1998b).

M arvell, Thomas B., and C arl E. M oody, The Impact of E nhanced Priosn Terms for Felonies Committed with $\mathrm{G}$ uns," Criminology 33 (M ay 1995).

Petee, Thomas A., Kathy G. Padgett, and Thomas York, "D ebunking the Sterotype: An Examination of $M$ ass $M$ urder in Public Places," H omi dide Studies 1 (N ovember 1997): 317-337.

Plassman, Florenz and T. Nicolaus Tideman, "D oes the Right to Carry Concealed $\mathrm{H}$ andguns Deter Countable Crimes?: O nly a Count A nalysis Can Say," Virginia Polytechnic Institute W orking Paper (O ctober 9,1998$)$.

Reuters N ewswire, "Police praise man in PA dance hall shooting," Sunday, A pril 26, 1998.

Zimring, Franklin, "T he $M$ edium is the $M$ essage: Firearm $C$ aliber as a Determinant of Death from Assault," Journal Legal Studies, 1 (1972): 97-123. 
This paper is a draft dated February 27, 1999. All rights reserved. Readers with comments should address them to:

John R. L ott, Jr. John M. O lin F ellow in L aw and E conomics U niversity of $C$ hicago $L$ aw School

1111 E ast $60^{\text {th }}$ Street

Chicago, IL 60637 
Tabl e 1

The Number of Multipl e Victim Murders and Injuries in

Publ ic Shoot ings by Year and by the Presence of a Conceal ed Handgun Law

\begin{tabular}{|c|c|c|c|c|c|c|c|c|c|c|}
\hline \multirow{3}{*}{ Year } & \multicolumn{3}{|c|}{ All States } & \multicolumn{7}{|c|}{ States Without Nondiscretionary H andgun Law (Induding the District of Columbia) } \\
\hline & $\begin{array}{l}\text { \# of M urders } \\
\text { in Public } \\
\text { Shootings }\end{array}$ & $\begin{array}{c}\text { \# of Injuries } \\
\text { in Public } \\
\text { Shootings }\end{array}$ & $\begin{array}{l}\text { \#of Public } \\
\text { Shootings }\end{array}$ & $\begin{array}{l}\text { \#of States w/out } \\
\text { Non-discretionary } \\
\text { Concedled } \\
\text { H andgun Law }\end{array}$ & $\begin{array}{l}\text { \# of M urders } \\
\text { in Public } \\
\text { Shootings }\end{array}$ & $\begin{array}{c}\text { \# of Injuries } \\
\text { in Public } \\
\text { Shootings }\end{array}$ & $\begin{array}{c}\text { \#of } \\
\text { Shootings }\end{array}$ & $\begin{array}{l}\text { \% of Total } \\
\text { Deaths } \\
\text { (Column 5/ } \\
\text { Column 1) }\end{array}$ & $\begin{array}{l}\text { \% of Total } \\
\text { I njuries } \\
\text { (Column 6/ } \\
\text { Column 2) } \\
\end{array}$ & $\begin{array}{l}\text { \% of Total } \\
\text { D eaths } \\
\text { (Column 7/ } \\
\text { Column 3) }\end{array}$ \\
\hline & (1) & (2) & (3) & (4) & (5) & (6) & (7) & (8) & (9) & (10) \\
\hline 1977 & 19 & 46 & 7 & 43 & 19 & 46 & 7 & $100 \%$ & $100 \%$ & $100 \%$ \\
\hline 1978 & 14 & 12 & 8 & 43 & 14 & 12 & 8 & $100 \%$ & $100 \%$ & $100 \%$ \\
\hline 1979 & 23 & 77 & 13 & 43 & 20 & 74 & 12 & $87 \%$ & $96 \%$ & $92 \%$ \\
\hline 1980 & 30 & 51 & 11 & 43 & 22 & 46 & 8 & $73 \%$ & $90 \%$ & $73 \%$ \\
\hline 1981 & 44 & 60 & 30 & 43 & 37 & 50 & 27 & $84 \%$ & $83 \%$ & $90 \%$ \\
\hline 1982 & 32 & 92 & 20 & 43 & 28 & 92 & 19 & $87 \%$ & $100 \%$ & $95 \%$ \\
\hline 1983 & 19 & 36 & 18 & 43 & 16 & 22 & 14 & $84 \%$ & $61 \%$ & $78 \%$ \\
\hline 1984 & 56 & 76 & 26 & 43 & 53 & 73 & 24 & $95 \%$ & $96 \%$ & $92 \%$ \\
\hline 1985 & 38 & 45 & 24 & 43 & 34 & 37 & 21 & $89 \%$ & $82 \%$ & $88 \%$ \\
\hline
\end{tabular}




\begin{tabular}{|c|c|c|c|c|c|c|c|c|c|c|}
\hline 1986 & 41 & 54 & 21 & 42 & 41 & 52 & 20 & $100 \%$ & $96 \%$ & $95 \%$ \\
\hline 1987 & 44 & 73 & 36 & 42 & 41 & 69 & 34 & $93 \%$ & $95 \%$ & $94 \%$ \\
\hline 1988 & 49 & 90 & 35 & 41 & 47 & 85 & 32 & $96 \%$ & $94 \%$ & $91 \%$ \\
\hline 1989 & 49 & 84 & 31 & 40 & 39 & 79 & 24 & $80 \%$ & $94 \%$ & $77 \%$ \\
\hline 1990 & 29 & 53 & 22 & 37 & 20 & 43 & 20 & $69 \%$ & $81 \%$ & $91 \%$ \\
\hline 1991 & 58 & 68 & 22 & 34 & 53 & 58 & 18 & $91 \%$ & $85 \%$ & $82 \%$ \\
\hline 1992 & 31 & 55 & 18 & 33 & 29 & 54 & 17 & $94 \%$ & $98 \%$ & $94 \%$ \\
\hline 1993 & 87 & 83 & 33 & 33 & 83 & 76 & 30 & $95 \%$ & $92 \%$ & $91 \%$ \\
\hline 1994 & 15 & 20 & 10 & 33 & 13 & 19 & 9 & $87 \%$ & $95 \%$ & $90 \%$ \\
\hline 1995 & 26 & 11 & 11 & 29 & 23 & 11 & 10 & $88 \%$ & $100 \%$ & $91 \%$ \\
\hline
\end{tabular}


Tabl e 1 (cont inued)

\begin{tabular}{|c|c|c|c|c|c|c|c|}
\hline \multirow[b]{2}{*}{ Year } & \multicolumn{7}{|c|}{ States With Shall I ssue Concealed H andgun Law } \\
\hline & $\begin{array}{l}\text { \# of States } \\
\text { w/ Law }\end{array}$ & $\begin{array}{l}\text { \#of M urders in } \\
\text { Public Shootings }\end{array}$ & $\begin{array}{l}\text { \#of I njuries in } \\
\text { Public Shootings }\end{array}$ & \#of Shootings & $\begin{array}{l}\% \text { of Total } \\
\text { Deaths } \\
\text { (Column 12/ } \\
\text { Column 1) }\end{array}$ & $\begin{array}{l}\text { \% of Total } \\
\text { Injuries } \\
\text { (Column 13/ } \\
\text { Column 2) }\end{array}$ & $\begin{array}{l}\text { \% of Total } \\
\text { Deaths } \\
\text { (Column 14/ } \\
\text { Column 3) }\end{array}$ \\
\hline & (11) & $(12)$ & (13) & (14) & (15) & (16) & (17) \\
\hline 1977 & 8 & 0 & 0 & 0 & $0 \%$ & $0 \%$ & $0 \%$ \\
\hline 1978 & 8 & 0 & 0 & 0 & $0 \%$ & $0 \%$ & $0 \%$ \\
\hline 1979 & 8 & 3 & 3 & 1 & $13 \%$ & $4 \%$ & $8 \%$ \\
\hline 1980 & 8 & 8 & 5 & 3 & $27 \%$ & $10 \%$ & $27 \%$ \\
\hline 1981 & 8 & 7 & 10 & 3 & $16 \%$ & $17 \%$ & $10 \%$ \\
\hline 1982 & 8 & 4 & 0 & 1 & $13 \%$ & $0 \%$ & $5 \%$ \\
\hline 1983 & 8 & 3 & 14 & 4 & $16 \%$ & $39 \%$ & $22 \%$ \\
\hline 1984 & 8 & 3 & 3 & 2 & $5 \%$ & $4 \%$ & $8 \%$ \\
\hline 1985 & 8 & 4 & 8 & 3 & $11 \%$ & $18 \%$ & $12 \%$ \\
\hline 1986 & 9 & 0 & 2 & 1 & $0 \%$ & $4 \%$ & $5 \%$ \\
\hline
\end{tabular}




\begin{tabular}{|c|c|c|c|c|c|c|c|}
\hline 1987 & 9 & 3 & 4 & 2 & $7 \%$ & $5 \%$ & $6 \%$ \\
\hline 1988 & 10 & 2 & 5 & 3 & $4 \%$ & $6 \%$ & $9 \%$ \\
\hline 1989 & 11 & 10 & 5 & 7 & $20 \%$ & $6 \%$ & $23 \%$ \\
\hline 1990 & 14 & 9 & 10 & 2 & $31 \%$ & $19 \%$ & $9 \%$ \\
\hline 1991 & 17 & 5 & 10 & 4 & $9 \%$ & $15 \%$ & $18 \%$ \\
\hline 1992 & 18 & 2 & 1 & 1 & $6 \%$ & $2 \%$ & $6 \%$ \\
\hline 1993 & 18 & 4 & 7 & 3 & $5 \%$ & $8 \%$ & $9 \%$ \\
\hline 1994 & 18 & 2 & 1 & 1 & $13 \%$ & $5 \%$ & $10 \%$ \\
\hline 1995 & 22 & 3 & 0 & 1 & $12 \%$ & & $0 \%$ \\
\hline
\end{tabular}


Table 2

The Rate of Mul tipl e Vict im M urders and Injuries in

Publ ic Shoot ings by Year and by the Presence of a Conceal ed Handgun Law

\begin{tabular}{|c|c|c|c|c|c|c|c|c|}
\hline \multirow[b]{2}{*}{ Year } & \multicolumn{3}{|c|}{ States Without Shall I ssue Law } & \multicolumn{3}{|c|}{ States With Shall I ssue Law } & \multicolumn{2}{|c|}{$\begin{array}{c}\text { Comparison of Rates Between Two Types } \\
\text { of States }\end{array}$} \\
\hline & $\begin{array}{l}\text { \#of States w/out } \\
\text { Shall I ssue Law } \\
\text { (Including the } \\
\text { District of } \\
\text { Columbia) }\end{array}$ & $\begin{array}{l}\text { Murders and } \\
\text { I njuries in } \\
\text { Public } \\
\text { Shootings Per } \\
\text { 100,000 People }\end{array}$ & $\begin{array}{c}\text { \# of Shootings } \\
\text { Per 100,000 } \\
\text { People }\end{array}$ & $\begin{array}{l}\text { \#of States } \\
\text { w/ Shall } \\
\text { Issue Law }\end{array}$ & $\begin{array}{c}\text { M urders and } \\
\text { Injuries in Public } \\
\text { Shootings Per } \\
\text { 100,000 People }\end{array}$ & \begin{tabular}{|c} 
\# of Shootings \\
Per 100,000 \\
People
\end{tabular} & $\begin{array}{l}\text { Does the M urder } \\
\text { and I njury Rate in } \\
\text { States w/out Laws } \\
\text { Exceed the Rate in } \\
\text { States w/ Laws }\end{array}$ & \begin{tabular}{|c} 
Does the Shooting \\
Rate in States w/out \\
Laws Exceed the \\
Rate in States with \\
Laws
\end{tabular} \\
\hline 1977 & 43 & 0.033 & .004 & 8 & 0.000 & \begin{tabular}{|c|}
0 \\
\end{tabular} & \begin{tabular}{|c|} 
Yes \\
\end{tabular} & Yes \\
\hline 1978 & 43 & 0.013 & .007 & 8 & 0.000 & 0 & Yes & Yes \\
\hline 1979 & 43 & 0.046 & .011 & 8 & 0.031 & .003 & Yes & Yes \\
\hline 1980 & 43 & 0.033 & .004 & 8 & 0.067 & .010 & No & No \\
\hline 1981 & 43 & 0.041 & .012 & 8 & 0.087 & .009 & No & Yes \\
\hline 1982 & 43 & 0.057 & .009 & 8 & 0.020 & .004 & Yes & Yes \\
\hline 1983 & 43 & 0.018 & .014 & 8 & 0.086 & .012 & No & Yes \\
\hline 1984 & 43 & 0.058 & .012 & 8 & 0.030 & .021 & Yes & No \\
\hline 1985 & 43 & 0.032 & .010 & 8 & 0.060 & .024 & No & No \\
\hline 1986 & 42 & 0.042 & .006 & 9 & 0.009 & .002 & Yes & Yes \\
\hline
\end{tabular}




\begin{tabular}{|c|c|c|c|c|c|c|c|c|}
\hline 1987 & 42 & 0.050 & .014 & 9 & 0.033 & .004 & Yes & Yes \\
\hline 1988 & 41 & 0.063 & .019 & 10 & 0.021 & .004 & Yes & Yes \\
\hline 1989 & 40 & 0.057 & .010 & 11 & 0.037 & .031 & Yes & No \\
\hline 1990 & 37 & 0.034 & .013 & 14 & 0.031 & .002 & Yes & Yes \\
\hline 1991 & 34 & 0.061 & .005 & 17 & 0.022 & .002 & Yes & Yes \\
\hline 1992 & 33 & 0.045 & .004 & 18 & 0.004 & .001 & Yes & Yes \\
\hline 1993 & 33 & 0.085 & .013 & 18 & 0.015 & .001 & Yes & Yes \\
\hline 1994 & 33 & 0.017 & .005 & 18 & 0.004 & .0004 & Yes & Yes \\
\hline 1995 & 29 & 0.019 & .003 & 22 & 0.004 & .0008 & Yes & Yes \\
\hline Ave. & & 0.0423 & .009 & & 0.0288 & .0064 & Yes & Yes \\
\hline
\end{tabular}


Tabl e 3

The Fourt een St at es That Changed Their

Conceal ed $\mathrm{H}$ andgun Laws bet ween 1977 and 1995

(Each cel I shows the mean and the standard deviation in par ent heses.)

\begin{tabular}{|c|c|c|}
\hline & \multicolumn{2}{|c|}{$\begin{array}{l}\text { Fourteen States that Changed from Not H aving to } \\
\text { H aving a Shall I ssue Conceal ed H andgun Law }\end{array}$} \\
\hline & $\begin{array}{l}\text { Years during Which These States Did Not } \\
\text { Have Shall Issue Concealed H andgun Laws } \\
\text { (O bservations =200) }\end{array}$ & $\begin{array}{c}\text { Years During Which They Did Have } \\
\text { Shall I ssue Concealed } \mathrm{H} \text { andgun Laws } \\
\text { (Observations }=66 \text { ) }\end{array}$ \\
\hline $\begin{array}{l}\text { M urders in M ultiple Victim Public } \\
\text { Shootings Per } 100,000 \text { People }\end{array}$ & $\begin{array}{c}.026 \\
(.119) \\
\end{array}$ & $\begin{array}{c}.0028 \\
(.0093) \\
\end{array}$ \\
\hline $\begin{array}{l}\text { I njuries in M ultiple Victim Public } \\
\text { Shootings Per } 100,000 \text { People }\end{array}$ & $\begin{array}{l}.025 \\
(.099)\end{array}$ & $\begin{array}{l}.0044 \\
(.014)\end{array}$ \\
\hline $\begin{array}{l}\text { M urders and I njuries in M ultiple } \\
\text { Victim Public Shootings Per 100,000 } \\
\text { People }\end{array}$ & $\begin{array}{l}.051 \\
(.190)\end{array}$ & $\begin{array}{l}.007 \\
(.021)\end{array}$ \\
\hline $\begin{array}{l}\text { References to M ultiple Victim Public } \\
\text { Shootings in the First Section of the } \\
\text { New York Times Per 100,000 People }\end{array}$ & $\begin{array}{l}.0033 \\
(.023)\end{array}$ & $\begin{array}{c}.0003 \\
(.0016)\end{array}$ \\
\hline $\begin{array}{l}\text { Number of Shootings Per 100,000 } \\
\text { People }\end{array}$ & $\begin{array}{l}.0136 \\
(.0499)\end{array}$ & $\begin{array}{c}.002 \\
(.0061)\end{array}$ \\
\hline $\begin{array}{l}\text { Actual and Attempted Bombings Per } \\
100,000 \text { People }\end{array}$ & $\begin{array}{l}.600 \\
(.632)\end{array}$ & $\begin{array}{l}.6998 \\
(.492)\end{array}$ \\
\hline $\begin{array}{l}\text { Actual and Attempted I ncendiary } \\
\text { Bombings Per 100,000 People }\end{array}$ & $\begin{array}{l}.1468 \\
(.206)\end{array}$ & $\begin{array}{l}.1257 \\
(.124)\end{array}$ \\
\hline $\begin{array}{l}\text { Other Bomb Related I ncidents Per } \\
\text { 100,000 People }\end{array}$ & $\begin{array}{l}.863 \\
(.833)\end{array}$ & $\begin{array}{l}.757 \\
(.799)\end{array}$ \\
\hline $\begin{array}{l}\text { Total Explosive I ncidents Per 100,000 } \\
\text { People }\end{array}$ & $\begin{array}{c}1.610 \\
(1.277)\end{array}$ & $\begin{array}{c}1.571 \\
(1.059)\end{array}$ \\
\hline
\end{tabular}


Tabl e 4

Examining the Means for St at es that Changed Their Conceal ed Handgun Laws During the 1977 to 1995 Period

\begin{tabular}{|c|c|c|c|c|c|c|c|c|}
\hline \multirow[b]{2}{*}{$\begin{array}{l}\text { Years Before and } \\
\text { After the } \\
\text { Adoption of the } \\
\text { Law (Year } 1 \text { is } \\
\text { the first full } \\
\text { Year that the } \\
\text { Law is in Effect) }\end{array}$} & \multirow[b]{2}{*}{$\begin{array}{l}\text { Number } \\
\text { of States } \\
\text { that Fall } \\
\text { into that } \\
\text { Category }\end{array}$} & \multicolumn{7}{|c|}{ States that Changed Their Concealed H andgun Laws During the 1977-95 Period: Using State Avg's to Compute Rates } \\
\hline & & \begin{tabular}{|c|} 
Murders in \\
Multiple \\
Victim Public \\
Shootings Per \\
100,000 People
\end{tabular} & $\begin{array}{c}\text { Injuries in } \\
\text { Multiple } \\
\text { Victim Public } \\
\text { Shootings Per } \\
\text { 100,000 People }\end{array}$ & $\begin{array}{c}\text { M urders and } \\
\text { Injuries in } \\
\text { M ultiple Victim } \\
\text { Public } \\
\text { Shootings Per } \\
\text { 100,000 People }\end{array}$ & $\begin{array}{l}\text { The Number of } \\
\text { Shootings Per } \\
100,000 \text { People }\end{array}$ & $\begin{array}{l}\text { Total Number of } \\
\text { Murders in } \\
\text { Multiple Victim } \\
\text { Public Shootings } \\
\text { for all States in } \\
\text { this Category }\end{array}$ & $\begin{array}{l}\text { Total Number } \\
\text { of I njuries in } \\
\text { M ultiple Victim } \\
\text { Public } \\
\text { Shootings for } \\
\text { al States in this } \\
\text { Category }\end{array}$ & $\begin{array}{l}\text { Total Number of } \\
\text { M urders and } \\
\text { I njuries in } \\
\text { M ultipleVictim } \\
\text { Public Shootings } \\
\text { for all States in } \\
\text { this Category }\end{array}$ \\
\hline-8 & 14 & 0.0033 & 0.0175 & 0.0208 & 0.0060 & 4 & 20 & 24 \\
\hline-7 & $\overline{14}$ & 0.0033 & 0.0145 & 0.0177 & 0.0116 & 2 & 7 & 9 \\
\hline-6 & 14 & 0.0593 & 0.0349 & 0.0942 & 0.0307 & 12 & 11 & 23 \\
\hline-5 & $\overline{14}$ & 0.0055 & 0.0032 & 0.0087 & 0.0013 & 8 & 5 & 13 \\
\hline-4 & 14 & 0.0151 & 0.0235 & 0.0386 & 0.0141 & 16 & 16 & 32 \\
\hline-3 & 14 & 0.0064 & 0.0159 & 0.0223 & 0.0045 & 5 & 12 & 17 \\
\hline-2 & 14 & 0.0188 & 0.0041 & 0.0229 & 0.0102 & 6 & 4 & 10 \\
\hline-1 & 14 & 0.0570 & 0.0896 & 0.1467 & 0.0460 & 13 & 17 & 30 \\
\hline 0 & 14 & 0.0152 & 0.0277 & 0.0428 & 0.0154 & 20 & 25 & 45 \\
\hline
\end{tabular}




\begin{tabular}{|l|l|l|l|l|l|l|l|l|}
\hline 1 & 14 & 0.0034 & 0.0097 & 0.0131 & 0.0046 & 4 & 10 & ${ }^{14}$ \\
\hline 2 & 10 & 0.0033 & 0.0050 & 0.0083 & 0.0033 & 4 & 6 & 10 \\
\hline 3 & 10 & 0.0062 & 0.0046 & 0.0108 & 0.0008 & 8 & 6 & ${ }^{14}$ \\
\hline 4 & 10 & 0.0000 & 0.0166 & 0.0166 & 0.0003 & 0 & 2 & 2 \\
\hline 5 & 9 & 0.0000 & 0.0000 & 0.0000 & 0.0000 & 0 & 0 & 0 \\
\hline 6 & 6 & 0.0049 & 0.0061 & 0.0110 & 0.0024 & 4 & 5 & 9 \\
\hline 7 & 3 & 0.0048 & 0.0024 & 0.0072 & 0.0024 & 2 & 1 & 3 \\
\hline 8 & 2 & 0.0000 & 0.0000 & 0.0000 & 0.0000 & 0 & 0 & 0 \\
\hline
\end{tabular}


Tabl e 5

Means and St andard Deviation of Variabl es

Shall Issue Law Dummy

Arrest Rate for Murder

M urders in M ultiple Victim Public Shootings Per 100,000 Persons

I njuries in Multiple Victim Public Shootings Per 100,000 Persons

M urders and Injuries in M ultiple Victim Public Shootings Per 100,000 Persons

Murders in Multiple Victim Public Shootings

I njuries in M ultiple Victim Public Shootings

$M$ urders and I njuries in M ultiple Victim Public Shootings

Attempted or Actual Bombings Per 100,000 Persons

Attempted or Actual Incendiary Bombings Per 100,000 Persons

Attempted or Actual Other Bombing Incidents Per 100,000 Persons

Attempted or Actual Bombings

Attempted or Actual Incendiary Bombings

Attempted or Actual Other Bombing Incidents

Deaths per shooting

Injuries per Shooting

Deaths or I njuries per Shooting

Number of Shootings

Number of Shootings per 100,000 Persons

M urders per 100,000 Persons

Death Penalty Execution Rate

Waiting Period Dummy

NRA M embers Per 100,000 Persons

State Population

State Population Squared

Real Per Capita Personal Income

Real Per Capita I ncome M aintenance

Real Per Capita Unemployment Insurance Payment

$\begin{array}{ccc}\text { Obs. } & \text { Meen } & \text { Standard Deviation } \\ 969 & .22497 & .41778 \\ 953 & 89.4275 & 53.9812 \\ 969 & .01586 & .066083 \\ 969 & .021886 & .09133 \\ 969 & .03775 & .13236 \\ 969 & .72652 & 2.47185 \\ 969 & 1.1207 & 3.850898 \\ 969 & 1.84727 & 5.76515 \\ 969 & .568889 & .488192 \\ 969 & 8.12461 & 19.16359 \\ 969 & .709398 & .6875484 \\ 969 & 26.20906 & 42.02015 \\ 969 & 8.12461 & 19.16359 \\ 969 & 28.44376 & 41.44581 \\ 239 & 1.707 & 1.54538 \\ 239 & 2.22 & 4.47260 \\ 239 & 4.525 & 4.83836 \\ 969 & .4087 & 1.01036 \\ 969 & .00888 & 0.0289133 \\ 966 & 7.56856 & 7.41677 \\ 966 & .0008941 & .0042598 \\ 969 & .3750877 & .47944 \\ 969 & 1231.408 & 674.4301 \\ 969 & 4718730 & 5115287 \\ 969 & 4.84 \mathrm{e}+13 & 1.20 \mathrm{e}+14 \\ 969 & 12874.66 & 2293.915 \\ 969 & 166.6172 & 66.8434 \\ 969 & 73.36105 & 44.88649 \\ & & \end{array}$


Real Retirement Payments Per Person Over 65 Population Density Per Square M ile

Unemployment Rate

Poverty Rate

Percent of the Population that is:

Black M ales 10 to 19 Years of Age

Black Females 10 to 19 Y ears of Age

White M ales 10 to 19 Years of Age

White Females 10 to 19 Years of Age

Other Males 10 to 19 Years of Age

Other Females 10 to 19 Years of Age

Black M ales 20 to 29 Years of Age

Black Females 20 to 29 Y ears of Age

White M ales 20 to 29 Years of Age

White Females 20 to 29 Years of Age

Other $M$ ales 20 to 29 Years of Age

Other Females 20 to 29 Years of Age

Black $M$ ales 30 to 39 Y ears of Age

Black Females 30 to 39 Y ears of Age

White M ales 30 to 39 Years of Age

White Females 30 to 39 Y ears of Age

Other M ales 30 to 39 Years of Age

Other Females 30 to 39 Years of Age

Black $M$ ales 40 to 49 Years of Age

Black Females 40 to 49 Y ears of Age

White M ales 40 to 49 Years of Age

White Females 40 to 49 Years of Age

Other $M$ ales 40 to 49 Years of Age

Other Females 40 to 49 Years of Age

Black $M$ ales 50 to 64 Years of Age

Black Females 50 to 64 Years of Age

White M ales 50 to 64 Years of Age

White Females 50 to 64 Y ears of Age

$\begin{array}{lcc}969 & 151.1192 & 55.0607 \\ 969 & 356.704 & 1399.525 \\ 969 & 6.564 & 2.1023 \\ 969 & 13.55103 & 4.223485 \\ & & \\ 969 & 1.00559 & 1.08956 \\ 969 & .9921156 & 1.10503 \\ 969 & 6.56392 & 1.560617 \\ 969 & 6.25813 & 1.526072 \\ 969 & .368235 & .732602 \\ 969 & .3557895 & .707472 \\ 969 & .946677 & 1.021947 \\ 969 & 1.024541 & 1.207095 \\ 969 & 7.205986 & 1.252604 \\ 969 & 7.05257 & 1.291831 \\ 969 & .3611558 & .7046579 \\ 969 & .3647368 & .7125971 \\ 969 & .7368627 & .8415113 \\ 969 & .8434159 & 1.00203 \\ 969 & 6.74614 & 1.214384 \\ 969 & 6.693695 & 1.203899 \\ 969 & .3143137 & .6723823 \\ 969 & .3460475 & .7103821 \\ 969 & .4893395 & .5828483 \\ 969 & .5763158 & .7112123 \\ 969 & 5.019412 & 1.049877 \\ 969 & 5.03807 & 1.024572 \\ 969 & .2131166 & .502547 \\ 969 & .2391022 & .5474948 \\ 969 & .5142621 & .6773694 \\ 969 & .6462745 & .8779527 \\ 969 & 5.727946 & 1.03609 \\ 969 & 6.147668 & 1.225103\end{array}$


Other $M$ ales 50 to 64 Years of Age Other Females 50 to 64 Years of Age

Black $M$ ales Over 64 Years of Age

Black Females Over 64 Years of Age

White $M$ ales Over 64 Years of Age

White Females Over 64 Years of Age

Other $M$ ales Over 64 Years of Age

Other Females Over 64 Y ears of Age

Violent Crime Rate Per 100,000 Persons

M urder Rate Per 100,000 Persons

Rape Rate Per 100,000 Persons

Aggravated Assault Rate Per 100,000 Persons

Robbery Rate Per 100,000 Persons

$\begin{array}{lll}969 & .2020537 & .6068594 \\ 969 & .2359133 & .6975253 \\ 969 & .3600516 & .4907798 \\ 969 & .5555728 & .8039973 \\ 969 & 4.337441 & 1.157958 \\ 969 & 6.324757 & 1.685616 \\ 969 & .1291434 & .4826889 \\ 969 & .1490402 & .5136774 \\ & & \\ 969 & 482.7601 & 338.3358 \\ 969 & 7.56856 & 7.416777 \\ 969 & 33.76551 & 16.04484 \\ 969 & 282.3533 & 177.0785 \\ 969 & 161.7178 & 176.6475\end{array}$


Appendix: Coefficient Est imat es for Regression Expl aining

Murders from Mul tipl e Vict im Publ ic Shootings

(Does not report the state and year fixed effects

that were included in the regression.)

Shall I ssue Law Dummy

Arrest Rate for $M$ urder

State Population

State Population Squared

Real Per Capita Personal Income

Real Per Capita I ncome Maintenance

Real Per Capita Unemployment I nsurance Payment

Real Retirement Payments Per Person Over 65

Unemployment Rate

Poverty Rate

Percent of the Population that is:

Black M ales 10 to 19 Years of Age

Black Females 10 to 19 Years of Age

White Males 10 to 19 Years of Age

White Females 10 to 19 Years of Age

Other Males 10 to 19 Years of Age

Other Females 10 to 19 Years of Age

Black M ales 20 to 29 Y ears of Age

Black Females 20 to 29 Years of A ge

White M ales 20 to 29 Years of Age

White Females 20 to 29 Years of Age

Other Males 20 to 29 Years of Age

Other Females 20 to 29 Years of Age

Black M ales 30 to 39 Years of Age

Black Females 30 to 39 Years of Age

$\begin{array}{cc}\text { Coefficient } & \text { t-statistics } \\ -.0608 & 2.766 \\ -.00027 & 1.597 \\ 5.11 \mathrm{e}-08 & 2.167 \\ -7.95 \mathrm{e}-16 & 1.618 \\ 4.74 \mathrm{e}-06 & 0.365 \\ .000078 & 0.317 \\ -5.28 \mathrm{e}-06 & 0.028 \\ .00109 & 1.795 \\ .0103159 & 1.999 \\ -.00212 & 0.832 \\ & \\ -.518476 & 1.169 \\ .62572 & 1.416 \\ .508906 & 2.169 \\ -.55929 & 2.275 \\ .94188 & 1.994 \\ -1.12658 & 2.292 \\ .50902 & 1.739 \\ -.30357 & 1.069 \\ -.310526 & 3.067 \\ .3187005 & 2.815 \\ .3769835 & 0.797 \\ -.252396 & 0.514 \\ -.92964 & 2.593 \\ .60665 & 2.119\end{array}$

Probability

0.006

0.111

0.031

0.106

0.715

0.751

0.977

0.073

0.046

0.406

0.243

0.157

0.030

0.023

0.046

0.022

0.082

0.285

0.002

0.005

0.425

0.607

0.010

0.034 
White M ales 30 to 39 Years of Age White Females 30 to 39 Years of Age Other M ales 30 to 39 Y ears of Age Other Females 30 to 39 Years of Age Black M ales 40 to 49 Years of Age Black Females 40 to 49 Years of Age White M ales 40 to 49 Years of Age White Females 40 to 49 Years of Age Other $M$ ales 40 to 49 Years of Age Other Females 40 to 49 Years of Age Black $M$ ales 50 to 64 Years of Age

Black Females 50 to 64 Years of Age White $M$ ales 50 to 64 Years of Age White Females 50 to 64 Years of Age Other $M$ ales 50 to 64 Years of Age Other Females 50 to 64 Years of Age Black $M$ ales Over 64 Y ears of Age Black Females Over 64 Years of Age White $M$ ales Over 64 Years of Age White Females Over 64 Years of Age Other $M$ ales Over 64 Y ears of A ge Other Females Over 64 Y ears of Age Intercept

Chi Square

Number of Observations

$\begin{array}{ccc}.31494 & 1.815 & 0.070 \\ -.37101 & 2.178 & 0.030 \\ -1.3244 & 2.135 & 0.033 \\ .67917 & 1.402 & 0.161 \\ -.201499 & 0.482 & 0.630 \\ .20465 & 0.525 & 0.599 \\ -.12779 & 0.721 & 0.471 \\ .19292 & 1.081 & 0.280 \\ .1767997 & 0.287 & 0.774 \\ -.56335 & 1.037 & 0.300 \\ .11955 & 0.273 & 0.785 \\ -.72681 & 1.814 & 0.070 \\ -.14827 & 0.889 & 0.374 \\ .12739 & 0.929 & 0.353 \\ .92883 & 1.627 & 0.104 \\ 1.0097 & 1.785 & 0.075 \\ -.29203 & 0.594 & 0.553 \\ .37786 & 1.115 & 0.265 \\ .060696 & 0.420 & 0.675 \\ -.02943 & 0.312 & 0.755 \\ 1.1684 & 1.490 & 0.136 \\ -1.0168 & 1.528 & 0.127 \\ -.02097 & -0.017 & 0.987\end{array}$

356.36

953 
Tabl e 6

The Impact of Shal I Issue Conceal ed Handgun Laws on Publ ic Shoot ings and Bombings

(The regressions use the tobit procedure The regressions include the following independent variables: detailed demographic information by sex, race, and age; population and population squared; state unemployment rate; state poverty rate; real per capita personal income, unemployment payments, income maintenance payments; retirement payments; arrest rate of murder; and state and year fixed effects. A bsolute t-statistics are shown in parentheses.)

\begin{tabular}{|c|c|c|c|c|c|c|}
\hline \multirow[b]{2}{*}{$\begin{array}{l}\text { Exogenous } \\
\text { Variables }\end{array}$} & \multicolumn{6}{|c|}{ Endogenous Variables } \\
\hline & $\begin{array}{c}\text { Murders in } \\
\text { Multiple } \\
\text { Victim Public } \\
\text { Shootings Per } \\
\text { 100,000 People }\end{array}$ & $\begin{array}{c}\text { Injuries in } \\
\text { M ultiple } \\
\text { Victim Public } \\
\text { Shootings Per } \\
\text { 100,000 People }\end{array}$ & $\begin{array}{c}\text { M urders and } \\
\text { Injuries in } \\
\text { M ultiple Victim } \\
\text { Public Shootings } \\
\text { Per 100,000 People }\end{array}$ & $\begin{array}{l}\text { M urders in } \\
\text { Multiple Victim } \\
\text { Public Shootings }\end{array}$ & $\begin{array}{l}\text { Injuries in } \\
\text { Multiple Victim } \\
\text { Public Shootings }\end{array}$ & $\begin{array}{l}\text { M urders and I njuries } \\
\text { in Multiple Victim } \\
\text { Public Shootings }\end{array}$ \\
\hline & (1) & (2) & (3) & (4) & (5) & (6) \\
\hline $\begin{array}{l}\text { Shall I ssue } \\
\text { Law } \\
\text { Dummy } \\
\text { Variable }\end{array}$ & $\begin{array}{c}-.061 \\
(2.766)\end{array}$ & $\begin{array}{l}-.0582 \\
(1.658)\end{array}$ & $\begin{array}{l}-.111 \\
(2.467)\end{array}$ & $\begin{array}{l}-6.887 \\
(2.959)\end{array}$ & $\begin{array}{l}-6.473 \\
(2.208)\end{array}$ & $\begin{array}{l}-13.38 \\
(3.136)\end{array}$ \\
\hline $\begin{array}{l}\text { Chi- } \\
\text { Square }\end{array}$ & 356.36 & 384.04 & 361.96 & 619.5 & 720.60 & 723.22 \\
\hline $\begin{array}{l}\text { Number of } \\
\text { Observatio } \\
\text { ns }\end{array}$ & 953 & 953 & 953 & 953 & 953 & 953 \\
\hline
\end{tabular}




\begin{tabular}{|c|c|c|c|c|c|c|}
\hline \multirow[b]{2}{*}{$\begin{array}{l}\text { Exogenous } \\
\text { Variables }\end{array}$} & \multicolumn{6}{|c|}{ Endogenous Variables } \\
\hline & $\begin{array}{l}\text { Attempted or } \\
\quad \text { Actual } \\
\text { Bombings Per } \\
\text { 100,000 People }\end{array}$ & $\begin{array}{c}\text { Attempted or } \\
\text { Actual } \\
\text { I ncendiary } \\
\text { Bombings Per } \\
\text { 100,000 People }\end{array}$ & $\begin{array}{l}\text { Other Bombing } \\
\text { Incidents Per } \\
\text { 100,000 People }\end{array}$ & $\begin{array}{l}\text { Attempted or } \\
\text { Actual Bombings }\end{array}$ & $\begin{array}{l}\text { Attempted or } \\
\text { Actual I ncendiary }\end{array}$ & $\begin{array}{l}\text { Other Bombing } \\
\text { Incidents }\end{array}$ \\
\hline & $(7)$ & (8) & (9) & $(10)$ & $(11)$ & $(12)$ \\
\hline $\begin{array}{l}\text { Shall I ssue } \\
\text { Law } \\
\text { Dummy } \\
\text { Variable }\end{array}$ & $\begin{array}{l}-.0488 \\
(0.874)\end{array}$ & $\begin{array}{l}.0018 \\
(0.047)\end{array}$ & $\begin{array}{l}.00046 \\
(1.266)\end{array}$ & $\begin{array}{c}.965 \\
(0.215)\end{array}$ & $\begin{array}{l}-2.9798 \\
(0.762)\end{array}$ & $\begin{array}{l}13.76 \\
(2.034)\end{array}$ \\
\hline $\begin{array}{l}\text { Chi- } \\
\text { Square }\end{array}$ & 1077.7 & 688.01 & 804.98 & 2688.8 & 1371.66 & 1820.26 \\
\hline $\begin{array}{l}\text { Number of } \\
\text { Observatio } \\
\text { ns }\end{array}$ & 953 & 953 & 953 & 953 & 953 & 953 \\
\hline
\end{tabular}


Tabl e 7

The Time Trends in Publ ic Shoot ings and Bombings

Before and After the Impl ement ation of the Shal I Issue Laws

(The regressions use the tobit procedure and include the following independent variables: detailed demographic information by sex, race, and age; population, population squared, and state unemployment rate; state poverty rate; real per capita personal income, unemployment payments, income maintenance payments, retirement payments; arrest rate for murder; and state and year fixed effects. A bsolute t-statistics are shown in parentheses.)

\begin{tabular}{|c|c|c|c|c|c|c|}
\hline \multirow[b]{2}{*}{$\begin{array}{l}\text { Exogenous } \\
\text { Variables }\end{array}$} & \multicolumn{6}{|c|}{ Endogenous Variables } \\
\hline & $\begin{array}{c}\text { Murders in } \\
\text { Multiple } \\
\text { Victim Public } \\
\text { Shootings Per } \\
\text { 100,000 People }\end{array}$ & $\begin{array}{c}\text { Injuries in } \\
\text { Multiple } \\
\text { Victim Public } \\
\text { Shootings Per } \\
\text { 100,000 People }\end{array}$ & $\begin{array}{l}\text { Total M urders and } \\
\text { I njuries in } \\
\text { Multiple Victim } \\
\text { Public Shootings } \\
\text { Per } 100,000 \text { People }\end{array}$ & $\begin{array}{c}\text { Murders in } \\
\text { Multiple Victim } \\
\text { Public Shootings }\end{array}$ & $\begin{array}{l}\text { Injuries in } \\
\text { M ultiple Victim } \\
\text { Public Shootings }\end{array}$ & $\begin{array}{l}\text { Total M urders } \\
\text { and I njuries in } \\
\text { Multiple Victim } \\
\text { Public Shootings }\end{array}$ \\
\hline & $(1)$ & (2) & (3) & (4) & (5) & (6) \\
\hline $\begin{array}{l}\text { Time Trend for } \\
\text { Years Before the } \\
\text { Shall I ssue Law } \\
\text { Went into Effect }\end{array}$ & $\begin{array}{c}.0093 \\
(2.321)\end{array}$ & $\begin{array}{c}.0102 \\
(1.630)\end{array}$ & $\begin{array}{c}.0148 \\
(1.900)\end{array}$ & $\begin{array}{c}.8217 \\
(1.867)\end{array}$ & $\begin{array}{c}.7738 \\
(1.402)\end{array}$ & $\begin{array}{l}1.1283 \\
(1.461)\end{array}$ \\
\hline $\begin{array}{l}\text { Time Trend for } \\
\text { Years After the } \\
\text { Shall I ssue Law } \\
\text { Went into Effect }\end{array}$ & $\begin{array}{l}-.0222 \\
(3.507)\end{array}$ & $\begin{array}{c}-01888 \\
(1.879)\end{array}$ & $\begin{array}{l}-.0384 \\
(2.973)\end{array}$ & $\begin{array}{c}-2.7703 \\
(4.040)\end{array}$ & $\begin{array}{l}-1.915 \\
(2.229)\end{array}$ & $\begin{array}{l}-4.606 \\
(3.698)\end{array}$ \\
\hline $\begin{array}{l}\text { F-test for } \\
\text { Differences in } \\
\text { Time trends } \\
\text { (probability in } \\
\text { parentheses) }\end{array}$ & $\begin{array}{c}18.37 \\
(.0000)\end{array}$ & $\begin{array}{c}6.49 \\
(.0110)\end{array}$ & $\begin{array}{c}13.00 \\
(.0003)\end{array}$ & $\begin{array}{c}20.61 \\
(.0000)\end{array}$ & $\begin{array}{c}7.57 \\
(.0060)\end{array}$ & $\begin{array}{c}16.24 \\
(.0001)\end{array}$ \\
\hline Chi-Square & 367.55 & 388.07 & 369.17 & 632.81 & 723.40 & 730.55 \\
\hline Number of Obs. & 953 & 953 & 953 & 953 & 953 & 953 \\
\hline
\end{tabular}


Tabl e 8

Incl uding Other Gun Cont rol Laws and Death Penal ty Execution Rat es

(The regressions use the tobit procedure and indude the following independent variables: detailed demographic information by sex, race, and age; population, population squared, and state unemployment rate; state poverty rate; real per capita personal income, unemployment payments, income maintenance payments, retirement payments; arrest rate for murder; and state and year fixed effects. Absolute t-statistics are shown in parentheses.)

\begin{tabular}{|c|c|c|c|c|c|c|}
\hline & \multicolumn{6}{|c|}{ Endogenous Variables } \\
\hline $\begin{array}{l}\text { Exogenous } \\
\text { Variables }\end{array}$ & $\begin{array}{c}\text { Murders in } \\
\text { Multiple } \\
\text { Victim Public } \\
\text { Shootings Per } \\
\text { 100,000 People }\end{array}$ & $\begin{array}{c}\text { Injuries in } \\
\text { Multiple } \\
\text { Victim Public } \\
\text { Shootings Per } \\
\text { 100,000 People }\end{array}$ & $\begin{array}{l}\text { Total M urders and } \\
\text { I njuries in } \\
\text { Multiple Victim } \\
\text { Public Shootings } \\
\text { Per } 100,000 \text { People }\end{array}$ & $\begin{array}{l}\text { M urders in } \\
\text { Multiple Victim } \\
\text { Public Shootings }\end{array}$ & $\begin{array}{l}\text { Injuries in } \\
\text { M ultiple Victim } \\
\text { Public Shootings }\end{array}$ & $\begin{array}{l}\text { Total M urders } \\
\text { and I njuries in } \\
\text { Multiple Victim } \\
\text { Public Shootings }\end{array}$ \\
\hline & (1) & (2) & (3) & (4) & (5) & (6) \\
\hline $\begin{array}{l}\text { Time Trend for } \\
\text { Years Before the } \\
\text { Shall I ssue Law } \\
\text { Went into Effect }\end{array}$ & $\begin{array}{c}.0093 \\
(2.270)\end{array}$ & $\begin{array}{l}.0119 \\
(1.842)\end{array}$ & $\begin{array}{l}.0164 \\
(2.047)\end{array}$ & $\begin{array}{l}.7016 \\
(1.556)\end{array}$ & $\begin{array}{l}.7953 \\
(1.392)\end{array}$ & $\begin{array}{l}1.059 \\
(1.325)\end{array}$ \\
\hline $\begin{array}{l}\text { Time Trend for } \\
\text { Years After the } \\
\text { Shall I ssue Law } \\
\text { Went into Effect }\end{array}$ & $\begin{array}{l}-.0247 \\
(3.260)\end{array}$ & $\begin{array}{l}-.0218 \\
(1.911)\end{array}$ & $\begin{array}{c}-.042 \\
(2.789)\end{array}$ & $\begin{array}{l}-3.113 \\
(3.713)\end{array}$ & $\begin{array}{l}-2.1359 \\
(2.213)\end{array}$ & $\begin{array}{l}-5.07 \\
(3.472)\end{array}$ \\
\hline $\begin{array}{l}\text { Waiting Period } \\
\text { Dummy }\end{array}$ & $\begin{array}{c}.025 \\
(0.513)\end{array}$ & $\begin{array}{l}.0558 \\
(0.702)\end{array}$ & $\begin{array}{l}.0501 \\
(0.509)\end{array}$ & $\begin{array}{l}-.7575 \\
(0.127)\end{array}$ & $\begin{array}{l}-1.23 \\
(0.158)\end{array}$ & $\begin{array}{l}-1.652 \\
(0.151)\end{array}$ \\
\hline $\begin{array}{l}\text { Length of } \\
\text { Waiting Period } \\
\text { in Days }\end{array}$ & $\begin{array}{l}.00017 \\
(0.0111)\end{array}$ & $\begin{array}{c}-.011 \\
(0.427)\end{array}$ & $\begin{array}{l}-.00084 \\
(0.027)\end{array}$ & $\begin{array}{l}3.7184 \\
(1.199)\end{array}$ & $\begin{array}{c}4.233 \\
(0.969)\end{array}$ & $\begin{array}{l}6.777 \\
(1.148)\end{array}$ \\
\hline
\end{tabular}




\begin{tabular}{|c|c|c|c|c|c|c|}
\hline $\begin{array}{l}\text { Length of } \\
\text { Waiting Period } \\
\text { Squared }\end{array}$ & $\begin{array}{l}-.00064 \\
(0.474)\end{array}$ & $\begin{array}{l}-.0007 \\
(0.307)\end{array}$ & $\begin{array}{l}-.0016 \\
(0.614)\end{array}$ & $\begin{array}{l}-.4137 \\
(1.045)\end{array}$ & $\begin{array}{l}-.6252 \\
(1.101)\end{array}$ & $\begin{array}{l}-.801 \\
(1.058)\end{array}$ \\
\hline $\begin{array}{l}\text { Additional } \\
\text { Penalty for Using } \\
\text { Gun in the } \\
\text { Commission of a } \\
\text { Crime Dummy }\end{array}$ & $\begin{array}{l}-.00048 \\
(0.271)\end{array}$ & $\begin{array}{l}.0179 \\
(0.619)\end{array}$ & $\begin{array}{c}.017 \\
(0.485)\end{array}$ & $\begin{array}{c}.0037 \\
(0.002)\end{array}$ & $\begin{array}{l}1.777 \\
(0.711)\end{array}$ & $\begin{array}{c}2.551 \\
(0.755)\end{array}$ \\
\hline $\begin{array}{l}\text { Death Penalty } \\
\text { Execution Rate }\end{array}$ & $\begin{array}{l}-.8077 \\
(0.431)\end{array}$ & $\begin{array}{l}-1.91 \\
(0.624)\end{array}$ & $\begin{array}{l}-2.28 \\
(0.593)\end{array}$ & $\begin{array}{l}-187.02 \\
(0.878)\end{array}$ & $\begin{array}{l}-.81499 \\
(0.003)\end{array}$ & $\begin{array}{c}-1882.35 \\
(0.469)\end{array}$ \\
\hline $\begin{array}{l}\text { F-test for } \\
\text { Differences in } \\
\text { Time trends } \\
\text { (probability in } \\
\text { parentheses) }\end{array}$ & $\begin{array}{l}16.73 \\
(.0000)\end{array}$ & $\begin{array}{c}7.27 \\
(.0071)\end{array}$ & $\begin{array}{c}12.71 \\
(.0004)\end{array}$ & $\begin{array}{l}17.74 \\
(.0000)\end{array}$ & $\begin{array}{c}7.55 \\
(.0061)\end{array}$ & $\begin{array}{c}14.87 \\
(.0001)\end{array}$ \\
\hline Chi-Square & 369.75 & 393.76 & 373.65 & 642.40 & 728.87 & 739.63 \\
\hline $\begin{array}{l}\text { Number of } \\
\text { O bservations }\end{array}$ & 953 & 953 & 953 & 953 & 953 & 953 \\
\hline
\end{tabular}


Tabl e 9

News Stories on Mul tipl e Vict im Publ ic Shoot ings in the First Section of the New York Times

(Because the Tobit estimates reported in the first two columns did not converge when we included all the control variables from the earlier regressions, we replaced the state fixed effects with regional dummy variables. The OLS regressions in the third and fourth columns control for all variables used earlier. Absolute t-statistics are shown in parentheses.)

\begin{tabular}{|c|c|c|c|c|}
\hline \multirow{3}{*}{ Exogenous Variables } & \multicolumn{4}{|c|}{ Endogenous Variables } \\
\hline & \multicolumn{2}{|c|}{ Tobit Estimates } & \multicolumn{2}{|c|}{ Ordinary Least Squares Estimates } \\
\hline & $\begin{array}{l}\text { M ultiple Victim Public } \\
\text { Shooting Stories } \\
\text { A ppearing in the First } \\
\text { Section of the New York } \\
\text { Times Per } 100,000 \text { People } \\
\text { in a State }\end{array}$ & $\begin{array}{l}\text { Multiple Victim } \\
\text { Public Shooting } \\
\text { Stories A ppearing in } \\
\text { the First Section of } \\
\text { the New York Times }\end{array}$ & $\begin{array}{l}\text { M ultiple Victim Public } \\
\text { Shooting Stories } \\
\text { Appearing in the First } \\
\text { Section of the New York } \\
\text { Times Per 100,000 People } \\
\text { in a State }\end{array}$ & $\begin{array}{c}\text { M ultiple Victim Public } \\
\text { Shooting Stories } \\
\text { Appearing in the First } \\
\text { Section of the New York } \\
\text { Times }\end{array}$ \\
\hline $\begin{array}{l}\text { A) Estimates Using } \\
\text { Only a Simple } \\
\text { Dummy Variable }\end{array}$ & & & & \\
\hline $\begin{array}{l}\text { Shall I ssue Law } \\
\text { Dummy Variable }\end{array}$ & $\begin{array}{l}-.0305 \\
(3.645)\end{array}$ & $\begin{array}{l}-2.485 \\
(3.530)\end{array}$ & $\begin{array}{l}-.0025 \\
(1.635)\end{array}$ & $\begin{array}{l}-.2151 \\
(1.684)\end{array}$ \\
\hline Chi-Square & 239.06 & 363.31 & & \\
\hline F-statistic & & & 2.06 & 4.44 \\
\hline $\mathrm{R}^{2}$ & & & .1274 & .3787 \\
\hline $\begin{array}{l}\text { B) Estimates Using } \\
\text { Before and After } \\
\text { Time Trends }\end{array}$ & & & & \\
\hline
\end{tabular}




\begin{tabular}{|c|c|c|c|c|}
\hline $\begin{array}{l}\text { Time T rend for } \\
\text { Years Before the } \\
\text { Shall Issue Law } \\
\text { Went into E ffect }\end{array}$ & $\begin{array}{l}.0023 \\
(1.832)\end{array}$ & $\begin{array}{l}.1913 \\
(1.773)\end{array}$ & $\begin{array}{c}.0001899 \\
(0.823)\end{array}$ & $\begin{array}{l}.0096 \\
(0.502)\end{array}$ \\
\hline $\begin{array}{l}\text { Time Trend for } \\
\text { Years After the Shall } \\
\text { Issue Law Went into } \\
\text { Effect }\end{array}$ & $\begin{array}{l}-.0055 \\
(2.66)\end{array}$ & $\begin{array}{l}-.4126 \\
(2.434)\end{array}$ & $\begin{array}{l}-.00058 \\
(1.556)\end{array}$ & $\begin{array}{l}-.06212 \\
(2.009)\end{array}$ \\
\hline $\begin{array}{l}\text { F-test for } \\
\text { Differences in Time } \\
\text { trends (probability in } \\
\text { parentheses) }\end{array}$ & $\begin{array}{l}10.48 \\
(.0013)\end{array}$ & $\begin{array}{c}9.63 \\
(.0020)\end{array}$ & $\begin{array}{c}2.86 \\
(.0913)\end{array}$ & $\begin{array}{c}3.61 \\
(.0579)\end{array}$ \\
\hline Chi-Square & 234.39 & 358.70 & & \\
\hline F-statistic & & & 2.05 & 4.46 \\
\hline$R^{2}$ & & & .1277 & .3797 \\
\hline $\begin{array}{l}\text { Number of } \\
\text { Observations }\end{array}$ & 953 & 953 & 953 & 953 \\
\hline
\end{tabular}




\section{Table 10}

The Impact of Shal I Issue Conceal ed Handgun Laws on the

Number of Shootings and the Number of Deat hs or Injuries fromeach Shoot ing

(Equation (3) uses ordinary least squares while the other regressions use the tobit procedure The regressions include demographic information by sex, race, and age; population, population squared, and state unemployment rate; state poverty rate; real per capita personal income, unemployment payments, income maintenance payments, and retirement payments; and state and year fixed effects. Absolute t-statistics are shown in parentheses.)

\begin{tabular}{|c|c|c|c|c|c|}
\hline & \multicolumn{5}{|c|}{ Endogenous Variables } \\
\hline & $\begin{array}{c}\text { Deaths per } \\
\text { Shooting }\end{array}$ & $\begin{array}{l}\text { Injuries per } \\
\text { Shooting }\end{array}$ & $\begin{array}{l}\text { Deaths or Injuries } \\
\text { per Shooting }\end{array}$ & Number of Shootings & $\begin{array}{c}\text { Number of Shootings per } \\
100,000 \text { people }\end{array}$ \\
\hline \multicolumn{6}{|l|}{ Exogenous Variables } \\
\hline & (1) & $(2)$ & (3) & (4) & (5) \\
\hline $\begin{array}{l}\text { Shall I ssue Law } \\
\text { Dummy Variable }\end{array}$ & $\begin{array}{l}-2.246 \\
(2.749)\end{array}$ & $\begin{array}{l}-4.315 \\
(1.962)\end{array}$ & $\begin{array}{l}-6.139 \\
(2.020)\end{array}$ & $\begin{array}{l}-1.405 \\
(2.115)\end{array}$ & $\begin{array}{l}-.0172 \\
(2.145)\end{array}$ \\
\hline F-statistic & & & 1.72 & & \\
\hline $\mathrm{R}^{2}$ & & & .6067 & & \\
\hline \multirow[t]{2}{*}{ Chi-Square } & 182.01 & 214.90 & & 758.63 & 355.67 \\
\hline & (6) & (7) & (8) & (9) & (10) \\
\hline $\begin{array}{l}\text { Time Trend for } \\
\text { Years Before the } \\
\text { Shall I ssue Law } \\
\text { Went into Effect }\end{array}$ & $\begin{array}{l}-.0237 \\
(0.105)\end{array}$ & $\begin{array}{c}.7029 \\
(1.090)\end{array}$ & $\begin{array}{l}.44796 \\
(0.535)\end{array}$ & $\begin{array}{l}.2140 \\
(1.728)\end{array}$ & $\begin{array}{l}.0030 \\
(2.066)\end{array}$ \\
\hline
\end{tabular}




\begin{tabular}{|c|c|c|c|c|c|}
\hline $\begin{array}{l}\text { Time Trend for } \\
\text { Years After the } \\
\text { Shall I ssue Law } \\
\text { Went into Effect }\end{array}$ & $\begin{array}{l}-.6726 \\
(2.385)\end{array}$ & $\begin{array}{l}.9100 \\
(1.187)\end{array}$ & $\begin{array}{l}-1.635 \\
(1.568)\end{array}$ & $\begin{array}{l}.5870 \\
(3.069)\end{array}$ & $\begin{array}{l}.0053 \\
(2.404)\end{array}$ \\
\hline $\begin{array}{l}\text { F-test for } \\
\text { Differences in Time } \\
\text { trends (probability } \\
\text { in parentheses) }\end{array}$ & $\begin{array}{c}3.81 \\
(0.0534)\end{array}$ & $\begin{array}{c}3.50 \\
(0.0636)\end{array}$ & $\begin{array}{c}2.5 \\
(0.0885)\end{array}$ & $\begin{array}{c}12.88 \\
(0.0004)\end{array}$ & $\begin{array}{c}9.92 \\
(0.0017)\end{array}$ \\
\hline F-statistic & & & 1.68 & & \\
\hline$R^{2}$ & & & .6039 & & \\
\hline Chi-Square & 180.23 & 214.57 & & 767.41 & 361.23 \\
\hline $\begin{array}{l}\text { Number of } \\
\text { Observations }\end{array}$ & 234 & 234 & 234 & 953 & 953 \\
\hline
\end{tabular}


Tabl e 11

Do Shoot ings Produce Yet More Shoot ings?

(A bsolute t-statistics in parentheses. The regression also includes monthly dummy variables.)

\begin{tabular}{|c|c|c|c|c|c|c|c|c|}
\hline \multirow[b]{3}{*}{ Exogenous Variables } & \multicolumn{4}{|c|}{$\begin{array}{l}\text { Endogenous Variable: Number of } \\
\text { Shootings Per M onth }\end{array}$} & \multicolumn{4}{|c|}{$\begin{array}{c}\text { Endogenous Variable: First Differences in the } \\
\text { Number of Shootings Per M onth (For these } \\
\text { specifications the explanatory variables } \\
\text { for the number of shootings and the number of } \\
\text { New York Times articles are also } \\
\text { differenced and then lagged) }\end{array}$} \\
\hline & \multicolumn{3}{|c|}{ Tobit } & \multirow{2}{*}{$\begin{array}{c}\text { OLS } \\
(4)\end{array}$} & \multicolumn{2}{|c|}{ Tobit } & \multicolumn{2}{|c|}{ Cochrane-Orcutt } \\
\hline & (1) & $(2)$ & (3) & & (5) & (6) & $(7)$ & (8) \\
\hline $\begin{array}{l}\text { Number of Shootings in } \\
\text { Previous } M \text { onth }\end{array}$ & $\begin{array}{l}.1690 \\
(1.785)\end{array}$ & $\begin{array}{c}.1526 \\
(1.588)\end{array}$ & $\begin{array}{l}.1264 \\
(1.324)\end{array}$ & $\begin{array}{l}.1550 \\
(2.000)\end{array}$ & $\begin{array}{l}-.5362 \\
(5.136)\end{array}$ & $\begin{array}{l}-.5072 \\
(4.956)\end{array}$ & $\begin{array}{l}-.5048 \\
(4.881)\end{array}$ & $\begin{array}{l}-.5227 \\
(8.124)\end{array}$ \\
\hline $\begin{array}{l}\text { Number of Shootings Two } \\
\text { M onths Ago }\end{array}$ & $\cdots$ & $\begin{array}{l}.1039 \\
(1.084)\end{array}$ & $\begin{array}{l}.07761 \\
(0.812)\end{array}$ & & $\ldots$ & $\begin{array}{l}.0354 \\
(0.415)\end{array}$ & $\begin{array}{c}.0384 \\
(0.443)\end{array}$ & \\
\hline $\begin{array}{l}\text { Number of Shootings } \\
\text { Three M onths Ago }\end{array}$ & $\cdots$ & $\ldots$ & $\begin{array}{l}.1813 \\
(1.880)\end{array}$ & & $\cdots$ & $\ldots$ & $\begin{aligned}-.099 \\
(1.057)\end{aligned}$ & \\
\hline $\begin{array}{l}\text { Number of New York } \\
\text { Times Stories in the Front } \\
\text { Section in Previous M onth }\end{array}$ & $\begin{array}{l}-.2057 \\
(1.116)\end{array}$ & $\begin{array}{l}-.1825 \\
(0.983)\end{array}$ & $\begin{array}{l}-.1111 \\
(0.601)\end{array}$ & $\begin{array}{l}-.1367 \\
(0.921)\end{array}$ & $\begin{array}{l}.0411 \\
(0.208)\end{array}$ & $\begin{array}{r}-.313 \\
(1.317)\end{array}$ & $\begin{array}{r}-.320 \\
(1.312)\end{array}$ & $\begin{array}{l}0.0478 \\
(0.373)\end{array}$ \\
\hline $\begin{array}{l}\text { Number of New York } \\
\text { Times Stories in the Front } \\
\text { Section Two M onths Ago }\end{array}$ & $\cdots$ & $\begin{array}{l}-.09145 \\
(0.498)\end{array}$ & $\begin{array}{l}-.0634 \\
(0.348)\end{array}$ & & $\ldots$ & $\begin{array}{c}-.551 \\
(2.869)\end{array}$ & $\begin{array}{c}-.519 \\
(2.649)\end{array}$ & \\
\hline $\begin{array}{l}\text { Number of New York } \\
\text { Times' Stories in the Front } \\
\text { Section Three M onths Ago }\end{array}$ & $\cdots$ & $\cdots$ & $\begin{array}{l}.0428 \\
(0.237)\end{array}$ & & $\cdots$ & $\cdots$ & $\begin{array}{c}.0132 \\
(0.070)\end{array}$ & \\
\hline
\end{tabular}




\begin{tabular}{|c|c|c|c|c|c|c|c|c|}
\hline $\begin{array}{l}\text { Percentage of the Nation's } \\
\text { Population Covered by } \\
\text { Shall I ssue Laws }\end{array}$ & $\begin{array}{l}-9.432 \\
(3.616)\end{array}$ & $\begin{array}{l}-8.7729 \\
(3.212)\end{array}$ & $\begin{array}{l}-7.5203 \\
(2.711)\end{array}$ & $\begin{array}{l}-6.9996 \\
(3.313)\end{array}$ & $\begin{array}{l}-8.860 \\
(2.241)\end{array}$ & $\begin{array}{l}-9.201 \\
(2.330)\end{array}$ & $\begin{array}{l}-9.152 \\
(2.266)\end{array}$ & $\begin{array}{l}-8.174 \\
(2.660)\end{array}$ \\
\hline M onthly Time Trend & $\begin{array}{l}.01449 \\
(4.117)\end{array}$ & $\begin{array}{c}0.139 \\
(3.719)\end{array}$ & $\begin{array}{c}.0113 \\
(2.996)\end{array}$ & $\begin{array}{c}.0107 \\
(3.810)\end{array}$ & $\begin{array}{c}.0133 \\
(2.451)\end{array}$ & $\begin{array}{l}.0136 \\
(2.512)\end{array}$ & $\begin{array}{c}.0143 \\
(2.567)\end{array}$ & $\begin{array}{c}.0118 \\
(2.842)\end{array}$ \\
\hline I ntercept & $\begin{array}{c}.6236 \\
(1.431)\end{array}$ & $\begin{array}{c}.5393 \\
(1.221)\end{array}$ & $\begin{array}{c}.2627 \\
(0.571)\end{array}$ & $\begin{array}{c}.9917 \\
(2.851)\end{array}$ & $\begin{array}{l}-.7686 \\
(1.117)\end{array}$ & $\begin{array}{l}-.5465 \\
(0.769)\end{array}$ & $\begin{array}{l}-1.165 \\
(1.408)\end{array}$ & $\begin{array}{l}-.0769 \\
(0.159)\end{array}$ \\
\hline Chi Squared or F-statistic & 35.36 & 36.68 & 40.00 & $\begin{array}{c}2.47 \\
\mathrm{DW}=2.005\end{array}$ & 48.05 & 54.80 & 55.29 & $\begin{array}{c}6.23 \\
\text { transformed } \\
\mathrm{DW}=2.008\end{array}$ \\
\hline Number of Observations & 227 & 226 & 225 & 227 & 226 & 224 & 222 & 225 \\
\hline
\end{tabular}


Tabl e 12

Simul taneous Logit-Tobit Estimat es

(The regressions control for sex, race, age; population, population squared, state unemployment rate, state poverty rate, real per capita personal income, unemployment payments, income maintenance payments, retirement payments, arrest rate for murder and state and year fixed effects. The first stage estimates do not report the regional dummy variables that were in the regression. Absolute t-statistics are shown in parentheses.)

\begin{tabular}{|c|c|c|c|c|c|c|}
\hline $\begin{array}{l}\text { Second } \\
\text { Stage }\end{array}$ & \multicolumn{6}{|c|}{ Endogenous Variables } \\
\hline $\begin{array}{l}\text { Exogenous } \\
\text { Variables }\end{array}$ & $\begin{array}{c}\text { Murders in } \\
\text { M ultiple } \\
\text { Victim Public } \\
\text { Shootings Per } \\
\text { 100,000 People }\end{array}$ & $\begin{array}{c}\text { Injuries in } \\
\text { Multiple } \\
\text { Victim Public } \\
\text { Shootings Per } \\
\text { 100,000 People }\end{array}$ & $\begin{array}{c}\text { M urders and } \\
\text { Injuries in } \\
\text { Multiple Victim } \\
\text { Public Shootings } \\
\text { Per } 100,000 \text { People }\end{array}$ & $\begin{array}{c}\text { Murders in } \\
\text { Multiple Victim } \\
\text { Public Shootings }\end{array}$ & $\begin{array}{c}\text { Injuries in } \\
\text { Multiple Victim } \\
\text { Public Shootings }\end{array}$ & $\begin{array}{l}\text { M urders and I njuries } \\
\text { in M ultiple Victim } \\
\text { Public Shootings }\end{array}$ \\
\hline $\begin{array}{l}\text { Shall I ssue } \\
\text { Law Dummy } \\
\text { Variable }\end{array}$ & $\begin{array}{c}-.023 \\
(1.647)\end{array}$ & $\begin{array}{l}-.0743 \\
(3.110)\end{array}$ & $\begin{array}{l}-.0921 \\
(2.271)\end{array}$ & $\begin{array}{c}-2.6746 \\
(1.674)\end{array}$ & $\begin{array}{l}-10.36 \\
(4.371)\end{array}$ & $\begin{array}{c}-13.166 \\
(2.989)\end{array}$ \\
\hline Chi-Square & 330.90 & 421.88 & 365.44 & 580.15 & 723.25 & 690.13 \\
\hline $\begin{array}{l}\text { Number of } \\
\text { Observations }\end{array}$ & 892 & 892 & 892 & 892 & 892 & 892 \\
\hline
\end{tabular}




\begin{tabular}{|c|c|c|c|c|c|c|c|}
\hline $\begin{array}{l}\text { First Stage } \\
\text { Estimates }\end{array}$ & \multicolumn{7}{|c|}{ Exogenous Variables } \\
\hline $\begin{array}{l}\text { Endogenous } \\
\text { Variable }\end{array}$ & $\begin{array}{c}\text { NRA } \\
\text { M embership } \\
\text { Rate }\end{array}$ & $\begin{array}{c}\text { Lagged } \\
\text { Violent } \\
\text { Crime Rate }\end{array}$ & $\begin{array}{c}\text { Lagged } \\
\text { Property } \\
\text { Crime Rate }\end{array}$ & $\begin{array}{l}\text { Change in } \\
\text { Violent } \\
\text { Crime Rate }\end{array}$ & $\begin{array}{l}\text { Change in } \\
\text { Property } \\
\text { Crime Rate }\end{array}$ & $\begin{array}{l}\text { \% Rep. Pres. in } \\
\text { State Vote* Year } \\
\text { Dummy1977-78 }\end{array}$ & $\begin{array}{l}\text { \% Rep. Pres. in } \\
\text { State Vote*Year } \\
\text { Dummy1979-82 }\end{array}$ \\
\hline $\begin{array}{l}\text { Shall I ssue } \\
\text { Law } \\
\text { Dummy } \\
\text { Variable }\end{array}$ & $\begin{array}{l}.000302 \\
(1.682)\end{array}$ & $\begin{array}{l}-.00259 \\
(5.004)\end{array}$ & $\begin{array}{l}.00025 \\
(2.642)\end{array}$ & $\begin{array}{l}.00159 \\
(1.354)\end{array}$ & $\begin{array}{l}.00013 \\
(.916)\end{array}$ & $\begin{array}{c}.043 \\
(2.558)\end{array}$ & $\begin{array}{c}.038 \\
(2.641)\end{array}$ \\
\hline
\end{tabular}

\begin{tabular}{|c|c|c|c|c|c|c|c|}
\hline $\begin{array}{l}\text { First Stage } \\
\text { Estimates }\end{array}$ & \multicolumn{7}{|c|}{ Exogenous Variables } \\
\hline $\begin{array}{l}\text { Endogenous } \\
\text { Variable }\end{array}$ & $\begin{array}{c}\text { \% Rep. Pres. in } \\
\text { State Vote*Y ear } \\
\text { Dummy1983-86 }\end{array}$ & $\begin{array}{c}\text { \% Rep. Pres. in } \\
\text { State Vote*Year } \\
\text { Dummy1987-90 }\end{array}$ & $\begin{array}{l}\text { \% Rep. Pres. in } \\
\text { State Vote*Year } \\
\text { Dummy1991-94 }\end{array}$ & \begin{tabular}{c|} 
\% Rep. Pres. in \\
State Vote* Y ear \\
Dummy1995
\end{tabular} & $\begin{array}{l}\text { \% of the } \\
\text { State that is } \\
\text { White }\end{array}$ & $\begin{array}{c}\% \text { of the } \\
\text { State that is } \\
\text { Black }\end{array}$ & Chi-Square \\
\hline $\begin{array}{l}\text { Shall I ssue } \\
\text { Law Dummy } \\
\text { Variable }\end{array}$ & $\begin{array}{c}.033 \\
(2.646)\end{array}$ & $\begin{array}{c}.047 \\
(3.468)\end{array}$ & $\begin{array}{c}.0942 \\
(4.932)\end{array}$ & $\begin{array}{c}.083 \\
(5.116)\end{array}$ & $\begin{array}{c}.0314 \\
(2.226)\end{array}$ & $\begin{array}{c}.031 \\
(1.683)\end{array}$ & 161.55 \\
\hline
\end{tabular}

